Front cover. Bayou in southeastern Arkansas. Photograph by Ralph Montanus, U.S. Geological Survey. 


\section{Occurrence, Distribution, Sources, and Trends of Elevated Chloride Concentrations in the Mississippi River Valley Alluvial Aquifer in Southeastern Arkansas}

By Timothy M. Kresse and Brian R. Clark

In cooperation with the Boeuf-Tensas Regional Irrigation Water Distribution District

Scientific Investigations Report 2008-5193 


\section{U.S. Department of the Interior DIRK KEMPTHORNE, Secretary}

\section{U.S. Geological Survey \\ Mark D. Myers, Director}

\section{U.S. Geological Survey, Reston, Virginia: 2008}

For product and ordering information:

World Wide Web: http://www.usgs.gov/pubprod

Telephone: 1-888-ASK-USGS

For more information on the USGS--the Federal source for science about the Earth, its natural and living resources, natural hazards, and the environment:

World Wide Web: http://www.usgs.gov

Telephone: 1-888-ASK-USGS

Any use of trade, product, or firm names is for descriptive purposes only and does not imply endorsement by the U.S. Government.

Although this report is in the public domain, permission must be secured from the individual copyright owners to reproduce any copyrighted materials contained within this report.

Suggested citation:

Kresse, T.M., and Clark, B.R., 2008, Occurrence, distribution, sources, and trends of elevated chloride concentrations in the Mississippi River Valley alluvial aquifer in southeastern Arkansas: U.S. Geological Survey Scientific Investigations Report 2008-5193, 34 p. 


\section{Contents}

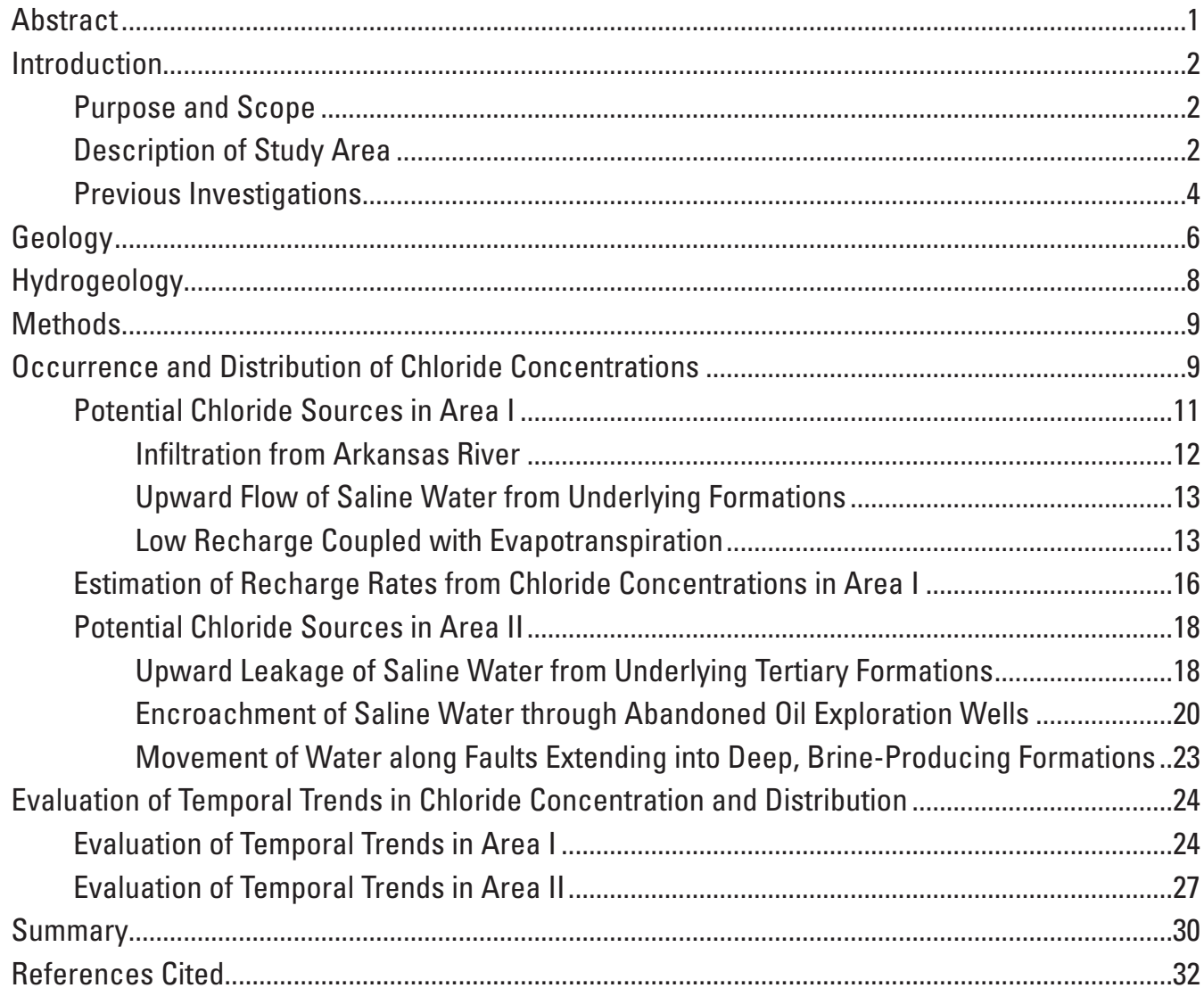

\section{Figures}

1-3. Maps showing:

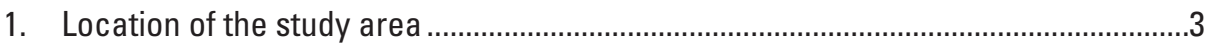

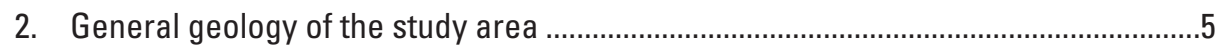

3. Distribution of chloride concentrations in ground-water samples from wells completed in the alluvial aquifer of southeastern Arkansas.

4. Graph showing chloride and bromide concentrations for ground-water samples from wells completed in Arkansas River alluvium near Dardanelle, Arkansas ...............13

5. Graph showing chloride and bromide concentrations for ground-water samples from wells completed in alluvial aquifer in the Bayou Bartholomew Basin

6-16. Maps showing:

6. Distribution of chloride concentrations in ground-water samples from wells completed in the upper Claiborne aquifer in Area I

7. Distribution of chloride concentrations in ground-water samples from wells completed in the alluvial aquifer in Area I overlain onto a map of Quaternary geomorphological landforms.

8. Distribution of chloride concentrations in ground-water samples from wells completed in the alluvial aquifer in Area I overlain onto a map of Quaternary geomorphological landforms. 
9. Distribution of alluvial aquifer chloride concentrations in Area II

10. Chloride isoconcentration contours for ground-water samples from wells completed in the upper Claiborne aquifer in Area II overlain on a shaded contour map of chloride concentrations in the alluvial aquifer.

11. Chloride concentrations in ground-water samples from three wells completed in the middle Claiborne aquifer and one well completed in the lower Claiborne aquifer in Area II overlain on a shaded contour map of chloride concentrations in the alluvial aquifer

12. Proposed zones of wrench faulting in the Jurassic Smackover Formation ......23

13. Potentiometric surface of water levels taken from wells in the alluvial aquifer in the winter of 2001 overlain on a chloride concentration shaded contour map

14. Distribution of chloride concentrations from wells in the alluvial aquifer in Area II overlain on a map of geomorphological landforms..... .26

15. Comparison of chloride concentration distribution for early (pre-1960) to late (post-1980) collection periods for Area I . .28

16. Comparison of early (pre-1985) U.S. Geological Survey data to late (2001) Arkansas Department of Environmental Quality data for Area II.

\section{Tables}

1. Stratigraphic column for the Lower Mississippi Valley.

2. Descriptive statistics for chloride concentrations for five counties in the study area ..11 


\section{Conversion Factors and Datums}

\begin{tabular}{|c|c|c|}
\hline Multiply & By & To obtain \\
\hline \multicolumn{3}{|c|}{ Length } \\
\hline foot $(\mathrm{ft})$ & 0.3048 & meter $(\mathrm{m})$ \\
\hline mile (mi) & 1.609 & kilometer $(\mathrm{km})$ \\
\hline \multicolumn{3}{|c|}{ Area } \\
\hline square mile $\left(\mathrm{mi}^{2}\right)$ & 259.0 & hectare (ha) \\
\hline square mile $\left(\mathrm{mi}^{2}\right)$ & 2.590 & square kilometer $\left(\mathrm{km}^{2}\right)$ \\
\hline \multicolumn{3}{|c|}{ Flow rate } \\
\hline gallon per minute (gal/min) & 3.785 & liter per minute $(\mathrm{L} / \mathrm{min})$ \\
\hline foot per day $(\mathrm{ft} / \mathrm{d})$ & 0.3048 & meter per day $(\mathrm{m} / \mathrm{d})$ \\
\hline million gllons per day (Mgal/d) & 0.04381 & cubic meter per second $\left(\mathrm{m}^{3} / \mathrm{s}\right)$ \\
\hline inch per year (in/yr) & 25.4 & millimeter per year $(\mathrm{mm} / \mathrm{yr})$ \\
\hline \multicolumn{3}{|c|}{ Hydraulic conductivity } \\
\hline foot per day (ft/d) & 0.3048 & meter per day $(\mathrm{m} / \mathrm{d})$ \\
\hline \multicolumn{3}{|c|}{ Hydraulic gradient } \\
\hline foot per mile $(\mathrm{ft} / \mathrm{mi})$ & 0.1894 & meter per kilometer $(\mathrm{m} / \mathrm{km})$ \\
\hline
\end{tabular}

Vertical coordinate information is referenced to the National Geodetic Vertical Datum of 1929 (NGVD of 1929).

Horizontal coordinate information is referenced to the North American Datum of 1983 (NAD 83).

Altitude, as used in this report, refers to distance above the vertical datum.

Specific conductance is given in microsiemens per centimeter at 25 degrees Celsius $\left(\mu \mathrm{S} / \mathrm{cm}\right.$ at $\left.25^{\circ} \mathrm{C}\right)$.

Concentrations of chemical constituents in water are given in milligrams per liter (mg/L) or micrograms per liter ( $\mu \mathrm{g} / \mathrm{L})$. 


\title{
Occurrence, Distribution, Sources, and Trends of Elevated Chloride Concentrations in the Mississippi River Valley Alluvial Aquifer in Southeastern Arkansas
}

\author{
By Timothy M. Kresse and Brian R. Clark
}

\section{Abstract}

Water-quality data from approximately 2,500 sites were used to investigate the distribution of chloride concentrations in the Mississippi River Valley alluvial aquifer in southeastern Arkansas. The large volume and areal distribution of the data used for the investigation proved useful in delineating areas of elevated (greater than 100 milligrams per liter) chloride concentrations, assessing potential sources of saline water, and evaluating trends in chloride distribution and concentration over time. Irrigation water containing elevated chloride concentrations is associated with negative effects to rice and soybeans, two of the major crops in Arkansas, and a groundwater chloride concentration of 100 milligrams per liter is recommended as the upper limit for use on rice. As such, accurately delineating areas with high salinity ground water, defining potential sources of chloride, and documenting trends over time is important in assisting the agricultural community in water management.

The distribution and range of chloride concentrations in the study area revealed distinct areas of elevated chloride concentrations. Area I includes an elongated, generally northwestsoutheast trending band of moderately elevated chloride concentrations in the northern part of the study area. This band of elevated chloride concentrations is approximately 40 miles in length and varies from approximately 2 to 9 miles in width, with a maximum chloride concentration of 360 milligrams per liter. Area II is a narrow, north-south trending band of elevated chloride concentrations in the southern part of the study area, with a maximum chloride concentration of 1,639 milligrams per liter. A zone of chloride concentrations exceeding 200 milligrams per liter is approximately 25 miles in length and 5 to 6 miles in width.

In Area I, low chloride concentrations in samples from wells completed in the alluvial aquifer next to the Arkansas River and in samples from the upper Claiborne aquifer, which underlies the alluvial aquifer, indicate that leakage from the river and upward flow of saline water in underlying aquifers are not likely sources for the saline water in the alluvial aquifer in Area I. A good comparison was noted for chloride concentrations in Area I and surface geomorphology. In the majority of cases, elevated chloride concentrations occurred in backswamp deposits, with low concentrations (less than 50 milligrams per liter) in areas of active or abandoned channel deposits. The fine-grained, clay-rich deposits associated with backswamp areas likely restrict recharge, induce increased ratios between evapotranspiration and recharge, and experience minimal flushing of salts concentrated during evapotranspiration.

In Area II, chloride isoconcentration maps of the underlying upper Claiborne aquifer, in addition to samples from wells completed in the middle and lower Claiborne aquifers, showed a similar chloride distribution to that of the alluvial aquifer with decreasing chloride concentrations to the east of the zone of elevated chloride concentrations, which suggests a deeper source of saline water that affects Tertiary and Quaternary aquifer systems. Mixing curves developed from bromide/ chloride ratios in water samples from the alluvial aquifer, Tertiary aquifers, and samples of brine water from the Jurrasic Smackover Formation additionally discounted upward flow of saline water from underlying Tertiary formations as a potential mechanism for salinity in the alluvial aquifer in Area II. A review of information on oil exploration wells in Chicot County revealed that most of these wells were drilled from 1960 to 1980 , after the elevated chloride concentrations were detected in the early 1950s. The elongated nature of the zone of elevated chloride concentrations in Area II suggests a line source or linear conduit connection with the source. Maps of a fractured limestone in the Smackover Formation in Arkansas, Mississippi, and Louisiana for purpose of hydrocarbon exploration revealed an intersection of two wrench faults in the vicinity of Area II. Upward movement of briny water in the Smackover Formation along these faults in southern Chicot County could introduce saline water into the alluvial aquifer.

County-level, temporal-trend comparisons of mean chloride concentrations in parts of Area I indicate that chloride concentrations have changed little since about 1950. Similarities were noted between general water quality collected in 1996 and that of previous investigations dating back to 1948 . However, no observable temporal trends in chloride concentrations were identified for Area I. Trend analysis was more 
difficult for Area II as insufficient data were available for earlier datasets. Data collected from 1950 from 1984 generally showed close agreement to a data set collected in 2001. The overall shape and size of the zone of elevated chloride concentrations has remained relatively static based on the available data.

\section{Introduction}

Ground water is arguably the most important natural resource in Arkansas and accounts for 66 percent of the total combined water use in the State. In 2005, approximately 7,510 million gallons per day (Mgal/d) was extracted from Arkansas' aquifers for all uses, including municipal, domestic, industrial, agricultural, and other uses (Holland, 2007). Irrigation is the greatest use of ground water in Arkansas (Holland, 2007), in spite of the fact that Arkansas receives mean precipitation of approximately 50 inches per year (in/yr) (Freiwald, 1984). Irrigation use accounted for $6,942 \mathrm{Mgal} / \mathrm{d}$ or 92 percent of the total ground water used during 2005. The Mississippi River Valley alluvial aquifer (hereafter referred to as the alluvial aquifer) in eastern Arkansas is the primary source of irrigation water and has the largest withdrawals of any aquifer in the State. In 2005, total use from the alluvial aquifer was 7,180 $\mathrm{Mgal} / \mathrm{d}$, as compared to $330 \mathrm{Mgal} / \mathrm{d}$ for the remaining combined aquifers in Arkansas (Holland, 2007).

In addition to the quantity of water necessary for irrigation purposes, water quality is an important factor for ensuring optimum crop production. One of the more important water-quality concerns related to agricultural production is high salinity water. Problems encountered in the use of high salinity waters (containing sodium and chloride) for irrigation in Arkansas occasionally include acute effects, such as the burning of crop foliage, and chronic effects including a reduction in the plants ability to take up water as a result of increased soil osmotic pressure (McFarland and others, 1998). Additionally, high sodium concentrations can cause soil structure deterioration and water infiltration problems (Cardon and Mortvedt, 2001; Gilmour, 2000). Salinity also has been shown to suppress uptake of some nutrients in plants, as well as suppression of other metabolic processes (Pulley and Beyrouty, 1996).

Use of ground water with high salinity negatively affects rice and soybean production, two major crops accounting for more than 75 percent of the irrigated acres in Arkansas. Soybeans are sensitive to chloride, especially where it accumulates in the upper soil profile from use of water with a high salt concentration. Various investigations have demonstrated that elevated soil salinity substantially reduces soybean emergence rate, shoot height, and root length (Wang and Shannon, 1999), in addition to increasing sudden death syndrome in soybeans (Rupe and others, 2000). Soil salinity additionally affects a significant amount of rice acreage in Arkansas each year (Wilson and others, 1997). Rice is particularly sensitive to chloride, especially at the seedling stage, which begins as leaf-tip burn and leads to stand loss with increasing exposure (Gilmour, 2000). For this reason, ground water that contains chloride concentrations exceeding 100 milligrams per liter $(\mathrm{mg} / \mathrm{L})$ is not recommended for rice production (Tacker and others, 1994).

Efforts to prevent rice or soybean injury from high salinity water, including treating of the soils with various amendments, has proven futile in Arkansas (Wilson and others, 1997). Because of this situation, accurately delineating areas with high salinity ground water, defining potential sources of chloride, and documenting trends over time is important in assisting the agricultural community in water management. In 2008, the U.S. Geological Survey (USGS) in cooperation with the Boeuf-Tensas Regional Irrigation Water Distribution District conducted a study to compile chloride concentrations for southeastern Arkansas and investigate the distribution and sources for the occurrence of saline water in parts of the alluvial aquifer of southeastern Arkansas.

\section{Purpose and Scope}

The primary purpose of this report is to compile waterquality data from various sources and show the regional occurrence, distribution, and source of chloride concentrations across a six-county study area in southeastern Arkansas. Included in the report is an evaluation of potential chloride sources, comparing the areas of elevated $(>100 \mathrm{mg} / \mathrm{L})$ chloride concentrations to surface geomorphology, soil type, potentiometric-surface maps, and underlying Tertiary aquifer water quality. The report summarizes evaluations of similar alluvial aquifer/stream systems using basic chemical fingerprinting techniques. An interpretation of trends in chloride concentrations also is presented, although lack of wells with long-term water-quality sampling prevented a statistical trend analysis.

\section{Description of Study Area}

The area of study for this report includes all or parts of six counties: Ashley, Desha, Drew, Chicot, Jefferson, and Lincoln, Counties (fig. 1). The area comprises approximately 3,200 square miles $\left(\mathrm{mi}^{2}\right)$ and encompasses three basins south of the Arkansas River: Bayou Bartholomew, Boeuf River, and Bayou Macon. The Arkansas and Mississippi Rivers act as hydrologic divides north and east of the study area, respectively. The Arkansas-Louisiana State line serves as a study area boundary to the south, and the western extent of the Bayou Bartholomew Basin boundary serves as a boundary to the west. This study area is the same area as in the Broom and Reed (1973) study, which referred to the area as the "Bayou Bartholomew Alluvial Aquifer-Stream System.” For this report, the area of investigation will be referred to simply as the "study area."

The study area represents a small portion of the Mississippi Alluvial Plain, which encompasses an area of approxi- 


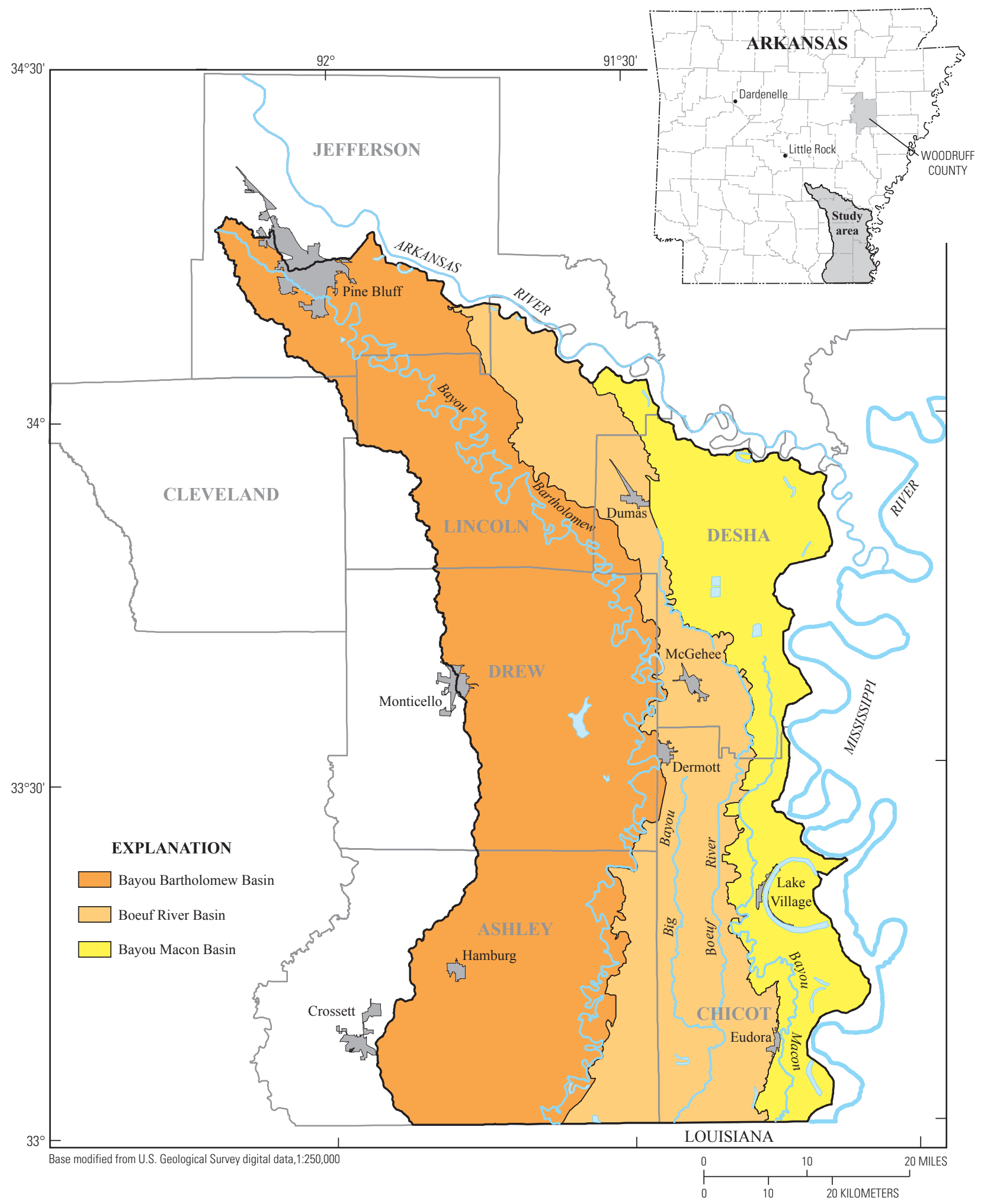

Figure 1. Location of the study area. 
mately 32,000 $\mathrm{mi}^{2}$ and includes parts of Arkansas, Illinois, Kentucky, Louisiana, Mississippi, Missouri, and Tennessee (Reed, 2004). Physiographic features defining the study area include abandoned channel deposits, natural levees, oxbow lakes, and backswamp areas (Krinitzsky and Wire, 1964). The land surface within the study area slopes at a rate of less than 1 foot per mile from an altitude of about 200 feet above National Geodetic Vertical Datum (NGVD) of 1929 at Pine Bluff to an altitude of about 100 feet above NGVD of 1929 at the Arkansas-Louisiana State line, and is characterized by sluggish streams, engineered canals, abandoned meanders, and oxbow lakes. West of Bayou Bartholomew, the flat-lying alluvial plain rises abruptly onto an elevated terrace of Pleistocene deposits (fig. 2) 20 feet or more above the flood-plain surface (Broom and Reed, 1973). In the southeastern part of Chicot County, another prominent feature stands out against the flood-plain deposits. The Macon Ridge is a 100 mile long narrow, Pleistocene terrace (fig. 2) that rises from 25 to 30 feet above the alluvial plain, north of Eudora, Arkansas, and extends into Louisiana to approximately the 32 degree latitude line (Krinitzsky and Wire, 1964).

Surface drainage in the area is into Bayou Bartholomew, Boeuf River, and Bayou Macon. Natural and artificial levees effectively prevent any drainage into the Mississippi River. The Bayou Bartholomew Basin is the largest of the three basins and has a drainage area of $1,480 \mathrm{mi}^{2}$, which is greater than the combined drainage area of 1,280 $\mathrm{mi}^{2}$ for Boeuf River $\left(780 \mathrm{mi}^{2}\right)$ and Bayou Macon $\left(500 \mathrm{mi}^{2}\right)$ (Broom and Reed, 1973). Although some farming takes place on the upland terraces of Ashley, Drew, Jefferson, and Lincoln Counties, silviculture dominates the land use in this area and most of the irrigation wells are completed in the flood-plain deposits of the study area (Kresse and Fazio, 2002). Although most farming occurs only within the narrow band of flood-plain alluvium, the six-county study area accounts for 16.5 percent of the total annual water use from the alluvial aquifer (Holland, 2007).

\section{Previous Investigations}

Several investigations have been published on water quality in the study area. A series of reports were made beginning in 1946 as part of a cooperative program between the USGS and the Arkansas Geological and Conservation Commission reference series (Hewitt and others, 1949; Klein and others, 1950; Bedinger and Reed, 1961; Onellion, 1956; Onellion and Criner, 1955). The primary purpose of the investigations was to provide information on the occurrence, availability, movement, recharge, discharge, and quality of water in various Arkansas counties in response to the increased demand of water for irrigation, community supply, and industrial uses. These early reports provide a historical reference for evaluating changes in water quality and assessing near-baseline conditions for parts of Jefferson (Klein and others, 1950), Desha and Lincoln (Bedinger and Reed, 1961),
Drew (Onellion, 1956), Ashley (Hewitt and others, 1949), and Chicot (Onellion and Criner, 1955) Counties. Onellion and Criner (1955) showed elevated chloride concentrations with a maximum of $1,490 \mathrm{mg} / \mathrm{L}$ in the southwestern part of Chicot County. They did not cite a specific source for the elevated chloride, but listed upward flow from underlying formations as a possible source. Bedinger and Reed (1961) listed chloride concentrations ranging from 3 to $182 \mathrm{mg} / \mathrm{L}$ in parts of Desha and Lincoln Counties. They noted a belt 6 to 8 miles south of the Arkansas River that contained patches of elevated $(>100$ $\mathrm{mg} / \mathrm{L}$ ) chloride concentrations. Although the report did not list a specific mechanism for the elevated chloride concentrations, the authors noted that the northern extent was close to the Arkansas River, which had a mean chloride concentration of $131 \mathrm{mg} / \mathrm{L}$ in 1952.

Bedinger and Jeffery (1964) reported on ground-water conditions in the lower Arkansas River Valley. The authors listed two wells in Jefferson County that contained elevated chloride and sulfate, which they attributed to influence from the Arkansas River. However, they noted that there were many wells with the same elevated concentrations that were separated from the river by water of lower background quality, and stated that there was no satisfactory explanation for the poorer water-quality type.

Broom and Reed (1973) reported on hydrologic conditions in the entire study area with a brief discussion on water quality. The authors, similar to Onellion and Criner (1955), attributed elevated chloride concentrations in Chicot County to possible upward flow of water from underlying Tertiary formations (table 1), although they noted that water from the upper Claiborne aquifer yielded satisfactory water for domestic and municipal water supply in eastern and northern Chicot County. The moderately elevated chloride concentrations in Lincoln and Desha Counties were broadly attributed to controls within the aquifer-stream system. The variations of chloride concentrations in this area were related to variations in aquifer transmissivity and other factors including evapotranspiration.

Fitzpatrick (1985) reported on the occurrence of saltwater in the alluvial aquifer in the Boeuf-Tensas Basin in southeastern Arkansas. The area of study generally equates to that of the present study area. Ground-water samples from 275 wells were collected from 1982 through 1984. The report presented additional water-quality data in the area of elevated chloride concentrations in Chicot County documented in Onellion and Criner (1955), with a maximum concentration of $1,360 \mathrm{mg} / \mathrm{L}$ in one well sample. In the northern part of the basin in Desha and Lincoln Counties, an area of elevated chloride concentrations was mapped south of the Arkansas River, with a maximum chloride concentration of $360 \mathrm{mg} / \mathrm{L}$. This area closely corresponded to the area previously documented in Bedinger and Reed (1961). Sources of elevated chloride concentrations throughout the basin were attributed to possible upward flow from high-salinity Tertiary aquifers, where the VicksburgJackson confining unit was absent or thinning. In the northern part of the basin, the Arkansas River was listed as a potential 


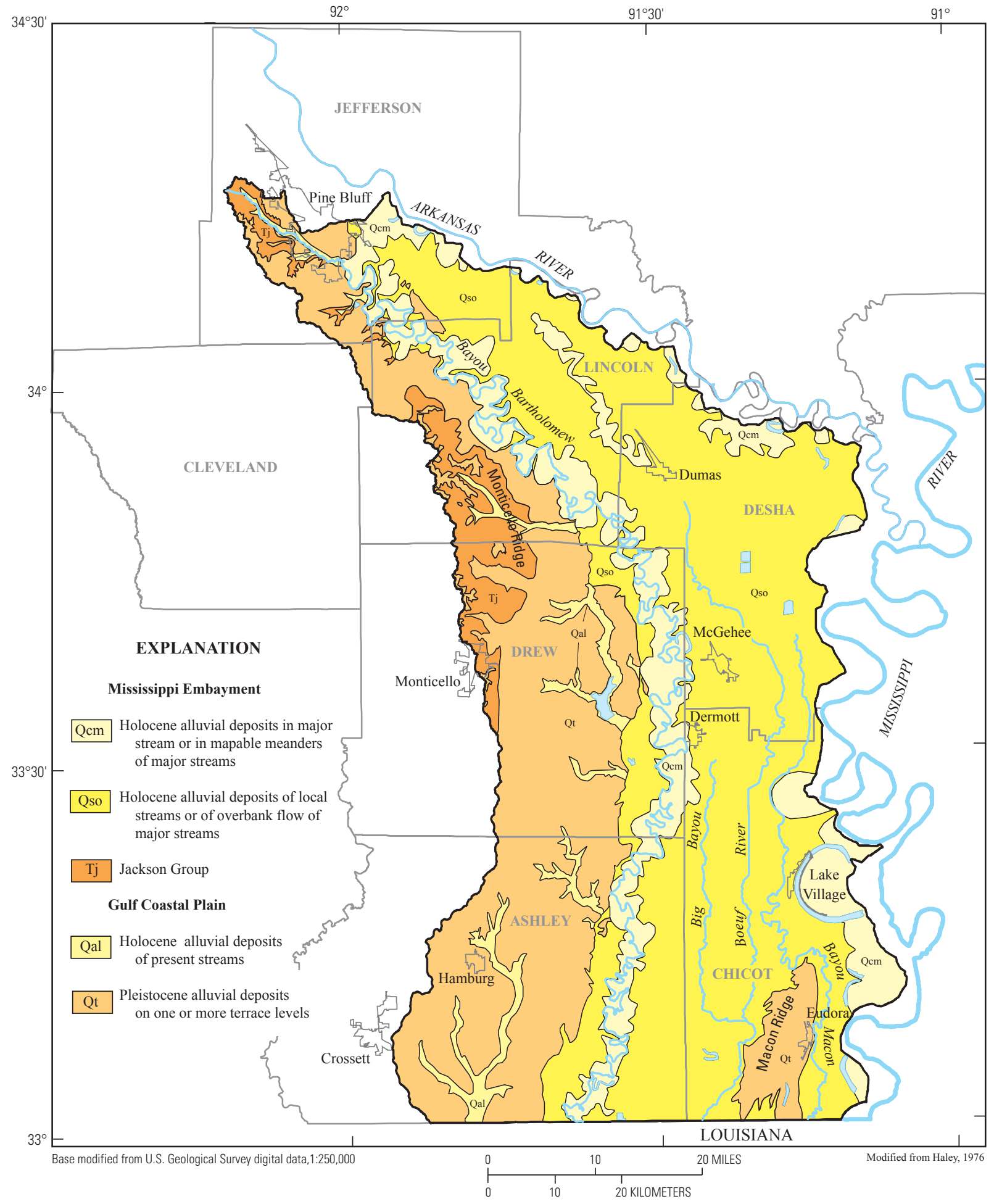

Figure 2. General geology of the study area. 
source, and in the southern part of the basin (Chicot County), abandoned oil and gas wells and possible faults were listed as specific sources, although no evidence was presented to either validate or refute potential sources.

Kresse and others (1997) reported on the occurrence of pesticides in the alluvial aquifer of eastern Arkansas, but additionally included major cations and anions and trace metal concentrations in the analyses. The authors compared general chemistry, including chloride concentrations, to older data sets from Klein and others (1950) for Jefferson County and Bedinger and Reed (1961) for Desha and Lincoln Counties. Based on isoconcentration maps of the area and comparison of mean concentrations between the data sets, the authors noted that little change had occurred over time in the occurrence, areal distribution, and concentration of chloride in ground water from the area.

Kresse and Fazio (2002) reported on the occurrence and distribution of pesticides, general water quality, and geochemical evolution of ground water in the alluvial aquifer in the Bayou Bartholomew Basin. Samples were collected from 120 irrigation wells in the basin, 25 of which were completed in the Pleistocene terrace deposits. Four of the samples from Jefferson and Lincoln Counties contained chloride concentrations greater than $100 \mathrm{mg} / \mathrm{L}$. The report summarized several potential salinity sources including infiltration from the Arkansas River, low recharge through overlying clays leading to minimal flushing and increased ground-water residence time, downward percolation of irrigation water enriched in salts by evapotranspiration, and upward flow of high salinity water from underlying Tertiary aquifers.

\section{Geology}

A brief review and basic understanding of the Quaternary geology (table 1) and geomorphology of the study area is important to inferences about the source and distribution of elevated chloride concentrations in the study area. Alluvial processes distribute and sort sediment of various sizes, which results in large areas of varying vertical and horizontal permeability. This results in an uneven distribution of recharge, flushing, and ground-water residence time, which can influence the geochemical evolution and affect the flow patterns of ground water. As such, knowledge of the lithologic variation within the alluvial deposits is a prerequisite to understanding and predicting the permeability and transmissivity of the alluvium and, as this report demonstrates, the chemical variation of the water stored and transmitted within the alluvium.

This report does not attempt to reconstruct the lengthy history associated with development of the Mississippi Embayment, the various glacial episodes and sea-level fluctuations, and the numerous levels and placement of ancient stream deposits that define the present geomorphic features of the Lower Mississippi Valley, but only presents an overview of the resulting landforms. For a thorough review of the geogra- phy, regional geologic framework, and stratigraphy and lithology within the Lower Mississippi Valley, the reader is directed to Saucier (1994).

Virtually all of the landforms within the study area are the direct result of fluvial processes. The dominant controls influencing the fluvial processes and resulting surface geology of the Lower Mississippi Valley were glaciation, climate, relative sea level, tectonism and subsidence; the single most important of these geologic processes was glaciation (Saucier, 1994). The Mississippi, Ohio, and Missouri Rivers all owe their existence to glacial sequences, and virtually all of the Pleistocene landforms in the study area are a direct result of meltwater and outwash from various periods of glaciation (Fisk, 1944; Saucier, 1994). The resulting landforms that occupy the area and influence the hydrology of the alluvial aquifer for the present investigation are valley-train, meanderbelt and backswamp deposits.

Valley trains (or braided streams) are characteristic of Pleistocene stream systems and are the direct result of deposition of coarse-grained glacial outwash by streams carrying large volumes of meltwater from receding glaciers. Wide, frequently branching channels separating irregular braid bars and interfluve areas are the most apparent and diagnostic recognition criteria for valley trains, and they are often mappable using aerial photographs and topographic maps. Saucier (1994) assigned various terrace levels to the valley trains based on age, relative position, and altitude of the deposits, which represent cyclic downcutting during waning glaciation. Pleistocene valley-train deposits in the study area are located in southern Chicot County, which represent outwash from the Mississippi and Ohio Rivers, and in western Lincoln, Drew, and Ashley Counties, which represent outwash from the Mississippi, Arkansas, and Red Rivers.

The onset of the Holocene is reflected in a change from the bedload-dominated braided streams to suspended-loaddominated meandering streams, which are typical of the modern-day streams within the Mississippi River Valley. Meander belts develop when a river has a relatively low gradient, a high suspended load/bedload ratio, is bordered by cohesive bank materials, has a relatively steady discharge, and is responding to a relatively constant base level (Saucier, 1994). Deposits directly associated with meander belts include natural levees and point bars, both of which are very permeable and are important sources of recharge to the alluvial aquifer within the study area (Bedinger and Reed, 1961; Bedinger and Jeffery, 1964). Backswamps are flat, shallow, and poorly drained areas associated with overbank flooding of meander-belt streams. As a generalization, backswamps include areas of thick, massive sequences of fine-grained overbank deposits (Saucier, 1994). Channel-fill deposits are abandoned channels, such as oxbow lakes, that often are completely filled with fine-grained flood deposits. Backswamp and channel-fill deposits are characterized by low permeable materials and are poor sources of aquifer recharge (Bedinger and Reed, 1961; Bedinger and Jeffery, 1964). Backswamp deposits occupy parts of Jefferson and Lincoln, and large parts of Desha Counties and are shown 
Table 1. Stratigraphic column for the Lower Mississippi Valley (modified from Saucier, 1994; Hart and others, 2008).

\begin{tabular}{|c|c|c|c|c|c|c|}
\hline Era & System & Series & Group & $\begin{array}{c}\text { Formation } \\
\text { or unit }\end{array}$ & $\begin{array}{l}\text { Hydrologic } \\
\text { units }\end{array}$ & Lithology \\
\hline \multirow{22}{*}{ Cenozoic } & \multirow{6}{*}{ Quaternary } & Holocene & & Alluvium & \multirow{6}{*}{ 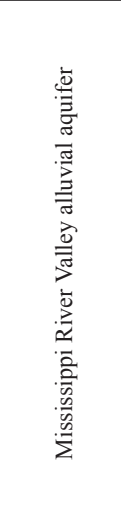 } & $\begin{array}{l}\text { Unconsolidated clays, silts, and sands deposited in } \\
\text { fluvial, deltaic, lacustrine, and marine environments. } \\
\text { Includes meander belt and backswamp deposits. }\end{array}$ \\
\hline & & \multirow{5}{*}{ Pleistocene } & & Valley trains & & $\begin{array}{l}\text { Two sequences (Early and Late Wisconsin) of braided- } \\
\text { stream deposits consisting of massive sands and gravels. }\end{array}$ \\
\hline & & & & Loess & & $\begin{array}{l}\text { Five sheets of tan to light brown, lightly calcareous, } \\
\text { massive eolian silts of Late to Middle Pleistocene age. }\end{array}$ \\
\hline & & & & $\begin{array}{l}\text { Deweyville } \\
\text { Formation }\end{array}$ & & $\begin{array}{l}\text { Fluvial terrace with thin fine-grained topstratum and } \\
\text { thick coarse-grained substratum. }\end{array}$ \\
\hline & & & & $\begin{array}{l}\text { Prairie } \\
\text { Formation }\end{array}$ & & $\begin{array}{l}\text { Diverse time-transgressive depositional sequence } \\
\text { representing fluvial to marine environments. }\end{array}$ \\
\hline & & & & $\begin{array}{l}\text { Intermediate } \\
\text { Complex }\end{array}$ & & $\begin{array}{l}\text { Fluvial terrace deposits of well-oxidized clays, silts, } \\
\text { sands, and gravels. Includes Montgomery terrace. }\end{array}$ \\
\hline & \multirow{16}{*}{ Tertiary } & \multirow{6}{*}{ Oligocene } & & $\begin{array}{l}\text { Catahoula } \\
\text { Formation }\end{array}$ & \multirow{8}{*}{ 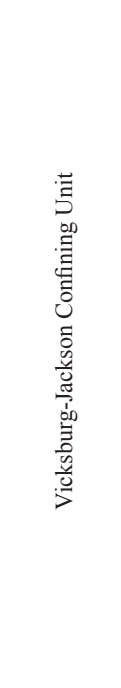 } & $\begin{array}{l}\text { Gray to white, tuffaceous siltstones and sandstones with } \\
\text { layers of loose, fine sands and thin clay layers. }\end{array}$ \\
\hline & & & \multirow{4}{*}{ Vicksburg } & $\begin{array}{l}\text { Bucatunna } \\
\text { Clay }\end{array}$ & & $\begin{array}{l}\text { Dark brown, lignitic clays of marine or estuarine origin. } \\
\text { Few thin siltstone layers. }\end{array}$ \\
\hline & & & & $\begin{array}{l}\text { Byram } \\
\text { Formation }\end{array}$ & & $\begin{array}{l}\text { Highly fossiliferous marine clays and sandy marks with } \\
\text { zones of nodular or lenticular limestone. }\end{array}$ \\
\hline & & & & $\begin{array}{l}\text { Glendon } \\
\text { Formation }\end{array}$ & & $\begin{array}{l}\text { Alternating thick layers of hard, sandy limestones and } \\
\text { clayey, sandy marls. }\end{array}$ \\
\hline & & & & $\begin{array}{l}\text { Mint Springs } \\
\text { Formation }\end{array}$ & & $\begin{array}{l}\text { Fossiliferous, sandy and clayey marls with occasional } \\
\text { phosphatic and lignitic pebbles. }\end{array}$ \\
\hline & & & & $\begin{array}{l}\text { Forest Hill } \\
\text { Formation }\end{array}$ & & $\begin{array}{l}\text { Clayey, lignitic silts irregularly interbedded with fine, } \\
\text { crossbedded sands and thin layers of clayey lignite. }\end{array}$ \\
\hline & & \multirow{8}{*}{ Eocene } & & Yazoo Clay & & $\begin{array}{l}\text { Dark gray, massive clays with widely scattered, irregular } \\
\text { zones of silty clays. Occasionally fossiliferous. }\end{array}$ \\
\hline & & & Jackson & $\begin{array}{l}\text { Moodys } \\
\text { Branch } \\
\text { Formation }\end{array}$ & & $\begin{array}{l}\text { Fossiliferous, sandy and clayey marls with occasional } \\
\text { layers and nodular zones. }\end{array}$ \\
\hline & & & \multirow{5}{*}{ Claiborne } & $\begin{array}{l}\text { Cockfield } \\
\text { Formation }\end{array}$ & $\begin{array}{l}\text { Upper } \\
\text { Claiborne } \\
\text { aquifer }\end{array}$ & $\begin{array}{l}\text { Lenticular, alternating, thin strata of gray to gray-brown } \\
\text { clays and light gray silts or silty sands. Scattered lignite } \\
\text { fragments and layers. }\end{array}$ \\
\hline & & & & $\begin{array}{c}\text { Cook } \\
\text { Mountain }\end{array}$ & $\begin{array}{l}\text { Middle } \\
\text { Claiborne } \\
\text { confining } \\
\text { unit }\end{array}$ & $\begin{array}{l}\text { Thick, brown, hard clays and reddish, clayey limonite } \\
\text { alternating with thin beds of glauconitic sands. }\end{array}$ \\
\hline & & & & Sparta Sand & $\begin{array}{l}\text { Middle } \\
\text { Claiborne } \\
\text { aquifer }\end{array}$ & $\begin{array}{l}\text { Massive, light gray, fine to medium sands interbedded } \\
\text { with thin layers of brown, lignitic sandy clays. Includes } \\
\text { Memphis Sand. }\end{array}$ \\
\hline & & & & $\begin{array}{l}\text { Cane River } \\
\text { Formation }\end{array}$ & $\begin{array}{l}\text { Lower } \\
\text { Claiborne } \\
\text { confining } \\
\text { unit }\end{array}$ & $\begin{array}{l}\text { Green and brown, calcareous, glauconitic, and } \\
\text { fossiliferous clays, marls, and sands. Includes Kosciusko } \\
\text { Formation. }\end{array}$ \\
\hline & & & & Carrizo Sand & $\begin{array}{l}\text { Lower } \\
\text { Claiborne } \\
\text { aquifer }\end{array}$ & $\begin{array}{l}\text { Light gray to brownish-gray, fine to coarse, micaceous } \\
\text { sands. }\end{array}$ \\
\hline & & & Wilcox & $\begin{array}{l}\text { Undifferen- } \\
\text { tiated }\end{array}$ & $\begin{array}{l}\text { Wilcox } \\
\text { aquifer }\end{array}$ & $\begin{array}{l}\text { Fine to medium, lignitic sands and sandy clays and } \\
\text { lignite. Massive sands, some coarse and graveliferous, in } \\
\text { upper and basal parts. }\end{array}$ \\
\hline & & \multirow{2}{*}{ Paleocene } & \multirow{2}{*}{ Midway } & $\begin{array}{l}\text { Porters } \\
\text { Creek Clay }\end{array}$ & \multirow{2}{*}{$\begin{array}{l}\text { Midway } \\
\text { confining } \\
\text { unit }\end{array}$} & $\begin{array}{l}\text { Massive, gray, fissile shales, clay shales, and clays with } \\
\text { sandy clay beds. }\end{array}$ \\
\hline & & & & Clayton & & $\begin{array}{l}\text { Gray, calcareous, glauconitic, fossiliferous shales with } \\
\text { scattered lenses of white limestone near base. }\end{array}$ \\
\hline
\end{tabular}


to be a major influence on ground-water flow and geochemical evolution in the study area.

A large band of Tertiary deposits (Jackson Group, table 1; fig. 2) outcrops in the western part of Lincoln and Drew Counties in a long north-south trending prominence termed the "Monticello Ridge," with a maximum thickness of approximately 500 feet (Bedinger and Reed, 1961). In some places along the ridge there are overlying Pliocene sands and gravels. Although water from these formations was used in the past as domestic and farm-supply sources, the combined effects of poor yields, little movement, and resulting high mineralization made the Jackson Group a poor choice as a dependable water supply (Kresse and Fazio, 2002). Because there is no evidence of communication between water from the Jackson Group and surrounding Quaternary deposits, and no irrigation wells are completed in the Jackson Group, this area is omitted from further discussion in this report.

\section{Hydrogeology}

The Quaternary alluvium of the Mississippi River Valley is represented by an upward fining of sediments from the base to the surface and is loosely divided into two units based on sediment grain size. The lower part consists of coarse sands and gravels, which collectively form the part referred to as the alluvial aquifer. The upper part consists of fine sands, silts, and clays. Ackerman (1989) was the first to term these overlying sediments as the "Mississippi River Valley confining unit." This nomenclature for the upper part of the aquifer system is found throughout the literature, although vertical permeability varies widely throughout the Mississippi River Valley, and infiltration of rainfall through the upper part is the most important source of recharge to the aquifer. The aquifer is confined only where the alluvium topstratum is dominantly clay fraction, thick and continuous, such as in backswamp or flood-plain areas. In general, the alluvial aquifer system in the study area is an open hydrologic system with relatively rapid recharge and discharge, both natural and artificial (Kresse and Fazio, 2002).

Thickness of the Quaternary alluvium in the study area ranges from a feather edge, where alluvium rests on Tertiary formations in the western part of the study area, to a maximum thickness of approximately 250 feet with a median thickness of approximately 150 feet (Onellion and Criner, 1955; Klein and others, 1950, Bedinger and Reed, 1961; Onellion, 1956). Because the alluvium is approximately flat-lying at the surface, the thickness of the alluvium is controlled by the relief on the surface of the Tertiary rocks, and the thickest sections are found in ancient buried channels beneath the Quaternary deposits. Discontinuities in well logs used for cross sections suggest that alluvial material was eroded and redeposited in old terrace channels (Bedinger and Reed, 1961).

Because the Pleistocene and Holocene deposits have the coarsest materials at their base and the base of the Holocene deposits often represents a reworking of older Pleistocene valley-train and other deposits, all of the past investigations within the study area have suggested that these deposits are hydraulically connected and hydrologically should be considered as one unit (Hewitt and others, 1949; Bedinger and Reed, 1961; Onellion, 1956). Although these systems are hydraulically connected, recent studies have demonstrated distinct differences in the geochemistry of water from the Pleistocene terrace deposits and from the flood-plain deposits (Broom and Reed, 1973; Kresse and Fazio, 2002).

Prior to 1975, the most important source of recharge to the alluvial aquifer in the study area was consistently listed as precipitation (Bedinger and Reed, 1961; Bedinger and Jeffery, 1964; Onellion, 1956; Boswell and others, 1968; Whitfield, 1975). Ackerman (1989) lists leakage from the Mississippi River Valley confining unit as the dominant source of recharge, but even this input can be viewed as a delayed precipitation input. Bedinger and Reed (1961) stated that hydraulic gradients commonly show ground water flowing away from the river during high stage, but that the chemistry of water from wells close to the river suggests the dominant source of recharge was precipitation through the coarse channel deposits next to the river. Bank storage commonly affects water levels within 2 to 3 miles of large river systems including the Arkansas and Mississippi Rivers (Krinitzsky and Wire, 1964; Bedinger and Jeffery, 1964; Ackerman, 1989). As such, water flowing away from the river at high stage returns to the river from bank storage during low stage. Although heavy pumping combined with a clayey topstratum can create a situation of constant recharge from the Arkansas River, it is likely that bank storage still plays an important role in the aquiferstream relation for the study area.

Recharge to the water table by infiltrating precipitation is uneven throughout the Mississippi River Valley and is highly dependent on the sediment size of the various types of alluvial deposits. Point bar deposits are the most permeable of the surface materials in the alluvial plain, and are important sources of recharge. Natural levees are also very permeable, are well suited for agriculture, and are also important as areas of recharge. Backswamps include the low areas of the flood plain away from the main streams and natural levees and commonly are inundated during times of flood. Clay and silt are added to the backswamp deposits during flooding, with claysized particles dominating the deposits further from the stream channels. The heavy soils of the backswamp deposits are not suitable for agriculture, except rice, and are not important sources of recharge. They consist mainly of clay, silty sand, clayey silt, and locally contain much organic matter. When dry they commonly contain many small ironstone concretions that make up the typical "buckshot" clay. They are relatively impermeable and not important as areas of recharge (Bedinger and Reed, 1961).

One of the most important features of the alluvial aquifer as a source of irrigation water is the high yield necessary for crop production. The average yield for wells completed in the alluvium in the study area is approximately 1,600 gallons per 
minute (gal/min), although reported yields of up to 2,000 gal/ min are common throughout the area and yields greater than 3,000 gal/min have been reported within the study area (Klein and others, 1950; Onellion, 1956; Bedinger and Reed, 1961; Hewitt and others, 1949). The greatest yields commonly are associated with buried channels where alluvial thicknesses are greatest (Hewitt and others, 1949).

\section{Methods}

Water-quality data from approximately 2,500 sites in southeastern Arkansas were used to produce a map of the occurrence, distribution, and source of chloride concentrations in the study area. Approximately 900 sample sites with chloride concentrations were extracted from the USGS National Water Information System database. Samples were analyzed at the USGS National Water Quality Laboratory in Lakewood, Colorado, using methods described in Fishman (1993). Data were collected irrespective of dates and included data from the earlier reports referenced in the previous sections. Samples were collected and analyzed from 1946 to 2007. The most recent data were used where duplicate analyses existed for the same site. The Arkansas Department of Environmental Quality (ADEQ) in Little Rock, Arkansas, operates a water-quality laboratory; surface- and ground-water samples collected by the ADEQ Water Division are analyzed by U.S. Environmental Protection Agency (USEPA) approved methods with data stored at their Little Rock office. ADEQ chloride concentration data for approximately 410 ground-water samples collected from 1996 to 2000 were compiled together with the USGS data for preparation of the maps used in this report.

The University of Arkansas Cooperative Extension Service (CES) conducted a study in Desha County to assess chloride and bicarbonate concentrations in ground water (Wilson and others, 2000). In addition to chloride concerns, elevated bicarbonate concentrations in irrigation water can lead to phosphorus and zinc deficiency in soils (Wilson and others, 2000). The CES gathered chloride data from approximately 1,200 irrigation wells in Desha County from 1998 to 2000 , producing a high data-density chloride concentration map. The researchers employed field-reagent kits to estimate the chloride concentrations. Chloride concentrations in some samples greatly exceeded those in the USGS and ADEQ databases with 21 samples exceeding $400 \mathrm{mg} / \mathrm{L}, 7$ exceeding $500 \mathrm{mg} / \mathrm{L}$, and 1 sample with a concentration of $683 \mathrm{mg} / \mathrm{L}$. Maximum concentrations in Desha County in the USGS and ADEQ data were consistently less than $400 \mathrm{mg} / \mathrm{L}$; this observation may be explained by the possibility that field-reagent kits may record greater concentrations than approved USEPA and USGS laboratory methods or that earlier studies with lower sampling spatial densities may have missed areas with concentrations greater than $400 \mathrm{mg} / \mathrm{L}$. A visual comparison of the data sets showed a similar areal distribution of the CES data to that of the combined USGS and ADEQ data sets. As such, the greater number of analyses provided in the CES data proved very useful for purposes of comparison to potential source controls; however, because of the greater level of uncertainty associated with the use of field-reagent kits, these data should not be interpreted as representing absolute concentrations.

The investigation of potential sources of elevated chloride concentrations in the alluvial aquifer was aided by plotting the combined water-quality data using a geographical information system (GIS). Within the GIS program, other data layers were overlain onto the surface to visually inspect for comparisons in the distribution of chloride to potential controlling factors including hydrogeologic influences such as surface geomorphology, surface confining layer thickness, soil type and distribution, potentiometric-surface maps, and other geologic and hydrologic controls on ground-water geochemistry. Most of these data layers were developed previously by digitizing and georeferencing maps from USGS published reports. The Quaternary geology map (Saucier, 1994) used in this report was georeferenced from available online maps produced by the U.S. Army Corps of Engineers office in Vicksburg, Mississippi.

A chloride mass balance method of estimating recharge was used to assess recharge rates potentially resulting in elevated chloride concentrations, which basically were limited to areas of backswamp deposits and may be related to evapotranspiration coupled with low recharge. The reduced form of the chloride mass balance equation can be expressed:

$$
\mathrm{R}=\mathrm{P} \times \mathrm{Cp} / \mathrm{Cgw}
$$

where $\mathrm{R}$ is recharge (inches/year),

$\mathrm{P}$ is precipitation (inches/year),

$\mathrm{Cp}$ is chloride concentration in precipitation

(milligrams per liter), and

$\mathrm{Cgw}$ is chloride concentration in ground water

(milligrams per liter).

Data for chloride concentrations in precipitation were taken from the National Atmospheric Deposition Program (2008) and averaged over a 20-year period from 1985 to 2005, resulting in a mean concentration of $0.25 \mathrm{mg} / \mathrm{L}$. A value of 50 in/yr was used as representing the annual mean precipitation in Arkansas from 1951 to 1980 (Freiwald, 1984).

\section{Occurrence and Distribution of Chloride Concentrations}

The distribution and range of chloride concentrations in the study area reveal distinct areas of elevated $(>100 \mathrm{mg} / \mathrm{L})$ chloride concentrations (fig. 3). Based on the different sources of chloride as inferred by the findings of this investigation, the discussions below will focus on two separate areas defined as "Area I" and "Area II." Area I includes an elongated, generally northwest-southeast trending band of moderately elevated 


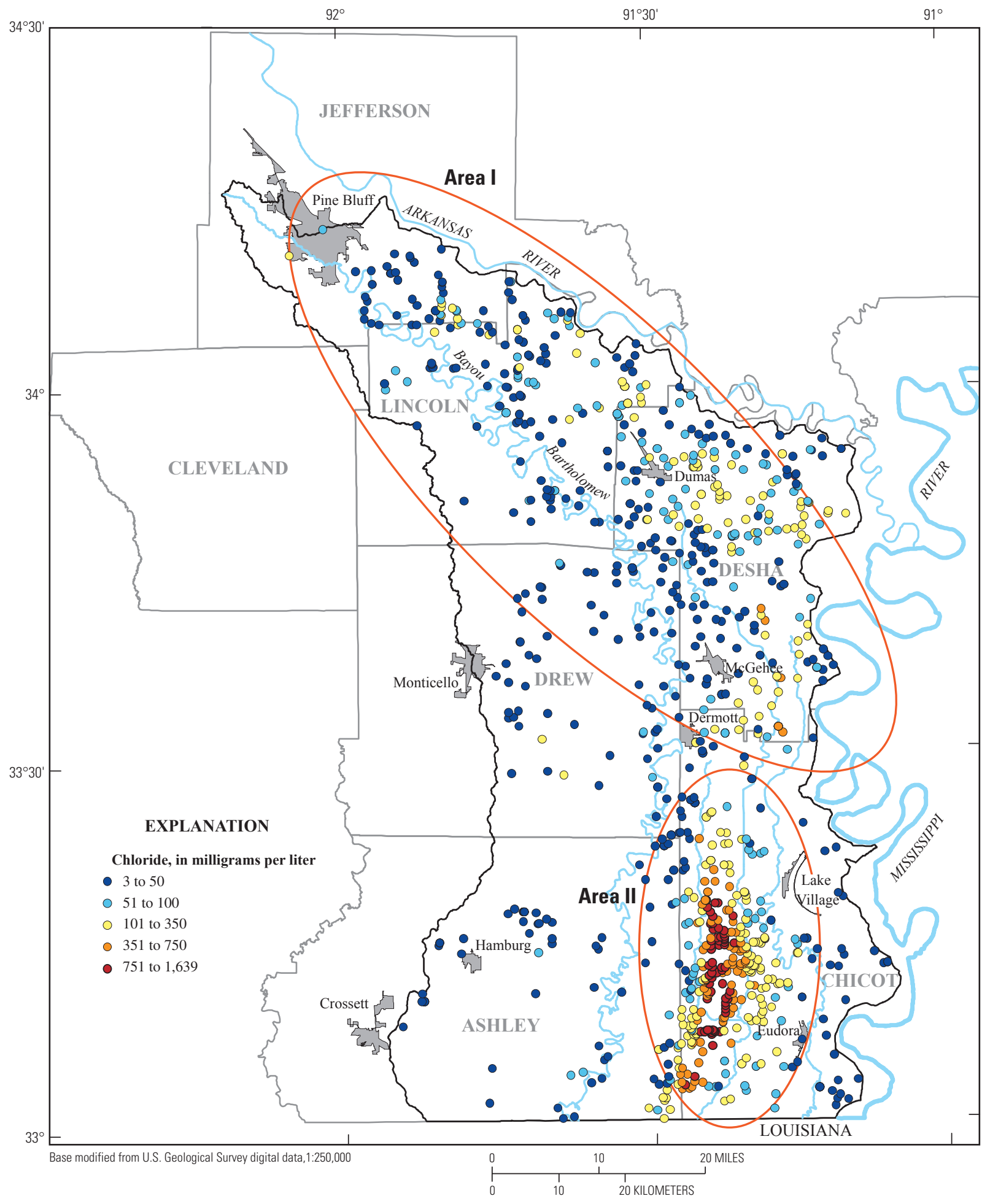

Figure 3. Distribution of chloride concentrations in ground-water samples from wells completed in the alluvial aquifer of southeastern Arkansas. 
chloride concentrations beginning in southeastern Jefferson County, extending through Lincoln County and a small part of northeastern Drew County, and into Desha County. This band of elevated chloride concentrations is approximately 40 miles in length and varies from approximately 2 miles in width in Jefferson County to approximately 9 miles or greater in Desha County. Area II is easily discerned from a casual review of figure 3 as a narrow, north-south trending zone of elevated chloride concentrations in southwestern Chicot County, represented by the predominance of orange (350-750 mg/L) and red $(>750 \mathrm{mg} / \mathrm{L})$ symbols. A zone of elevated chloride concentrations exceeding $200 \mathrm{mg} / \mathrm{L}$ is approximately 25 miles in length and 5 to 6 miles in width (Kresse and others, 2000).

A discussion of the occurrence and distribution of elevated chloride concentrations requires a brief discussion of the range of chloride concentrations, the establishment of baseline or background concentrations, and an adequate definition of the term "elevated" in relation to defined background concentrations. The range, mean, and median chloride concentrations vary substantially for five of the six counties in the study area (table 2). The elevated chloride concentrations

Table 2. Descriptive statistics for chloride concentrations for five counties in the study area.

[all units in milligrams per liter]

\begin{tabular}{lccccc}
\hline County & Minimum & Maximum & Median & Mean & $\begin{array}{c}\text { Number of } \\
\text { wells }\end{array}$ \\
\hline Ashley & 4 & 93 & 26 & 33 & 46 \\
Desha & 3 & 360 & 64 & 86 & 203 \\
Drew & 3 & 112 & 15 & 20 & 65 \\
Jefferson & 5 & 184 & 24 & 37 & 56 \\
Lincoln & 5 & 180 & 33 & 47 & 94 \\
\hline
\end{tabular}

in Area II (Chicot County) result from a deep brine source, and thus this area is not representative of the natural evolution of high salinity in the alluvial aquifer, such as within Area I (see sections below on potential chloride sources for each area). As such, statistical analyses for Chicot County are not included in the discussion. The lowest mean $(20 \mathrm{mg} / \mathrm{L})$ and median $(15$ $\mathrm{mg} / \mathrm{L}$ ) chloride concentrations occur in Drew County, which is dominated by Pleistocene terrace deposits in the west and Holocene alluvium associated with Bayou Bartholomew in the east. These concentrations are similar to the mean $(25 \mathrm{mg} / \mathrm{L})$ and median $(17 \mathrm{mg} / \mathrm{L})$ concentrations from Kresse and Fazio (2002) for the Bayou Bartholomew Basin, which is underlain by similar geology. Chloride concentrations were below 50 $\mathrm{mg} / \mathrm{L}$ in water samples from wells completed in the upland, Pleistocene terraces in western Drew and Ashley Counties, and in the channel deposits of the Bayou Bartholomew Basin. The increased mean and median concentrations in Desha,
Jefferson, and Lincoln Counties are the result of the inclusion of samples from the zone of elevated chloride concentrations in Area I. As such, in absence of a source of salinity leading to the increased concentrations reported for Area I and Area II ground water, mean and median concentrations should be expected not to exceed $25 \mathrm{mg} / \mathrm{L}$. As previously noted, the CES recommends a maximum of $100 \mathrm{mg} / \mathrm{L}$ chloride for optimum crop production (Tacker and others, 1994). Because of the recommended limit for use on crops, this report uses concentrations greater than $100 \mathrm{mg} / \mathrm{L}$ to represent "elevated" chloride concentrations. However, because most mean and median chloride concentrations were less than $50 \mathrm{mg} / \mathrm{L}$, with the exception of Desha County, figures for Area I employ a range of concentrations to include areas of low (3-50 mg/L) chloride concentrations and transition zones $(51-100 \mathrm{mg} / \mathrm{L})$ between areas with dominantly low and elevated chloride concentrations.

\section{Potential Chloride Sources in Area I}

Area I contains a northwest-southeast trending band of moderately elevated chloride concentrations with a maximum concentration of $360 \mathrm{mg} / \mathrm{L}$. Several mechanisms have been cited as potential sources for elevated chlorides in Area I. A review of the various investigations reporting on water quality in Area I (Bedinger and Reed, 1961; Bedinger and Jeffery, 1964; Broom and Reed, 1973; Fitzpatrick, 1985; Kresse and Fazio, 2002) resulted in the following hypothesized source mechanisms for elevated chloride concentrations in this area:

1. Infiltration from the Arkansas River, which has maximum chloride concentrations exceeding the chloride concentrations in the alluvial aquifer in Area I;

2. Upward flow of saline water from the underlying Tertiary aquifer system, where the confining layer has been thinned or removed;

3. Relatively low recharge rates leading to minimal flushing and increased residence time for ground water; and

4. Downward percolation of irrigation water that has been enriched in salts by evaporation at the surface.

Although it could provide a source of chloride locally, hypothesized source number 4 logically can be discounted as a general source by the fact that irrigation occurs throughout the study area, including those areas where chloride concentrations are low. One exception might include areas dominated by rice production, where large volumes of water are left standing on the land with an increased potential for evaporation. However, this type of farming occurs dominantly on clayey soils, in which the third hypothesized source, relatively low recharge rates and minimal flushing, would also be of concern. As such, the third and fourth hypothesized sources have been combined in the following discussion to include areas of relatively low recharge where slow percolation/minimal flushing coupled 
with evapotranspiration increases the salinity of percolating water.

For this report, flushing implies the piston displacement by recharging precipitation held in pores of the aquifer from previous infiltration periods. Evapotranspiration can extract much of the water phase, leaving behind solutes including various salts. Because sodium chloride salts are extremely soluble, recharging water dilutes and displaces minor salt accumulation where the unsaturated zone sediments are relatively coarse and permeable. Where clay confining layers obstruct the downward percolation and piston displacement of waters in the unsaturated zone, the buildup of salts over time from evapotranspiration may slowly leach to the water table resulting in areas of higher saline ground water associated with areas of clayey topstratum.

\section{Infiltration from Arkansas River}

Chloride concentrations in the Arkansas River vary seasonally and annually, with the greater concentrations occurring in the summer months and during drought years, respectively. Bedinger and Reed (1961) cited a weighted-average chloride content in the river of approximately $131 \mathrm{mg} / \mathrm{L}$ in 1952. Broom and Reed (1973) stated that the Arkansas River can contain up to $300 \mathrm{mg} / \mathrm{L}$ during periods of the year. Petersen (1988) provided a summary of water quality in selected rivers and streams in Arkansas for 1975 through 1985, including four sites on the Arkansas River downstream from and including Little Rock, Arkansas. Maximum chloride concentrations at the four sites ranged from $220 \mathrm{mg} / \mathrm{L}$ to $550 \mathrm{mg} / \mathrm{L}$, with mean concentrations ranging from $90 \mathrm{mg} / \mathrm{L}$ to $150 \mathrm{mg} / \mathrm{L}$ for the four sites. The greatest maximum concentration, although representing a single measurement, indicates that the Arkansas River is a potential source based solely on chloride concentrations. However, a cursory review of figure 3 reveals that chloride concentrations in most wells next to the river are less than $50 \mathrm{mg} / \mathrm{L}$. This situation alone tends to refute the Arkansas River as a potential source of high chloride concentrations.

Prior to the installation of the lock and dam system in 1967, the Arkansas River acted as a drain for ground-water flow for most of the year (Bedinger and Reed, 1961). Previous publications identified a ground-water ridge near the river that formed a divide between the water moving into the river and that moving away from the river. Although wells near the river exhibited high water levels during high river water stage, this effect was diminished exponentially away from the river and was small beyond a distance of approximately 2 miles (Krinitzsky and Wire, 1964; Bedinger and Jeffery, 1964; Bedinger and Reed, 1961; Ackerman, 1996). Ground-water chemistry in wells close to the Arkansas River provided evidence that most of the water recharging nearby was rainfall percolating through the more porous channel deposits surrounding the river, rather than infiltration from the river itself (Bedinger and Reed, 1961). Although installation of the lock and dam system has artificially raised river water elevations relative to ground water throughout most of the study area, rising and falling of stage in the river can result in a component of flow toward the river at times, and a ground-water divide may be prominent throughout various parts of the year that is not evident at the scale of more recent potentiometric-surface maps (Schrader, 2001; Reed, 2004). Such a divide was documented recently in the upper part of the Arkansas River near Dardanelle, Arkansas, less than 0.5 mile inland from the river (Kline and others, 2006), where flow was from the river during high river stage and towards the river during periods of declining river stage.

Recent investigations (Kresse and others, 1997; Kresse and Fazio, 2002), similar to earlier findings of Bedinger and Reed (1961), revealed chloride concentrations less than 50 $\mathrm{mg} / \mathrm{L}$ in wells closest to the river, which indicates very little influence by the Arkansas River on the alluvial aquifer. One water sample collected from a well within 0.8 mile of the river had a chloride concentration less than $20 \mathrm{mg} / \mathrm{L}$ (Kresse and others, 1997). Additionally, mean ground-water velocities in eastern Arkansas are approximately 0.25 foot/day (Kresse and Van Schaik, 1996). Using this velocity, a particle of water would take approximately 60 years to move a distance of 1 mile. Increasing the velocity by a factor of two to account for increased gradient near the river only shortens this timeframe to 30 years. In combination with the effects of bank storage, chemical effects of any recharge derived from increased river stage resulting from damming of the Arkansas River may not be detectable for several decades, even if the river now serves as a major source of recharge to ground water in the study area.

Kresse and others (2006) investigated the influence of the Arkansas River on the chemistry of water from production wells completed in the alluvial deposits near the river in Dardanelle, Arkansas, in western Arkansas outside of the study area. Water-quality samples were collected from 11 municipal production wells and 14 monitoring wells, in addition to samples from the Arkansas River. From a concentration of 9 $\mathrm{mg} / \mathrm{L}$ in the farthest inland municipal well (approximately 1 mile from the river), chloride concentrations increased to 24 , $31,42,62$, and $71 \mathrm{mg} / \mathrm{L}$ in five approximately equal-spaced wells trending toward the river, which had a concentration of $185 \mathrm{mg} / \mathrm{L}$; these results clearly reflect the influence of infiltration from the river. Background concentrations measured in four wells immediately upgradient from the production wells ranged from 9 to $16 \mathrm{mg} / \mathrm{L}$; however, three wells furthest inland from the background wells had chloride concentrations above background concentrations ranging from 37 to $69 \mathrm{mg} / \mathrm{L}$. These three wells were completed in a backswamp area with a thick, clayey top stratum (Kline and others, 2006). A graph of chloride and bromide concentrations showed two mixing lines, one with lower bromide/chloride ratios with the river as the source of salinity, and another trend, which included the furthest inland wells, with a different salinity source (fig. 4). Water from underlying Paleozoic rocks exhibited low chloride concentrations and the source was attributed to evapotranspiration, poor flushing, interaction with thick overlying clays, and increased residence time (Kresse and others, 2006). Using these same mixing lines, elevated chloride concentrations for 
samples from the Bayou Bartholomew Basin in Area I plot on the trend line defined by evapotranspiration, and not on the chloride/bromide trend for river water infiltration (fig. 5). This relation implies that the Arkansas River likely is not the source of the elevated chloride concentrations in Area I.

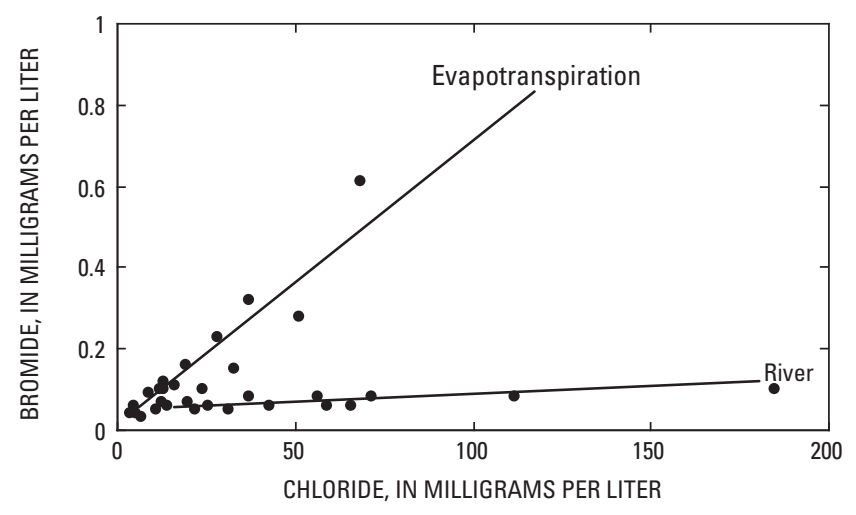

Figure 4. Chloride and bromide concentrations for ground-water samples from wells completed in Arkansas River alluvium near Dardanelle, Arkansas.

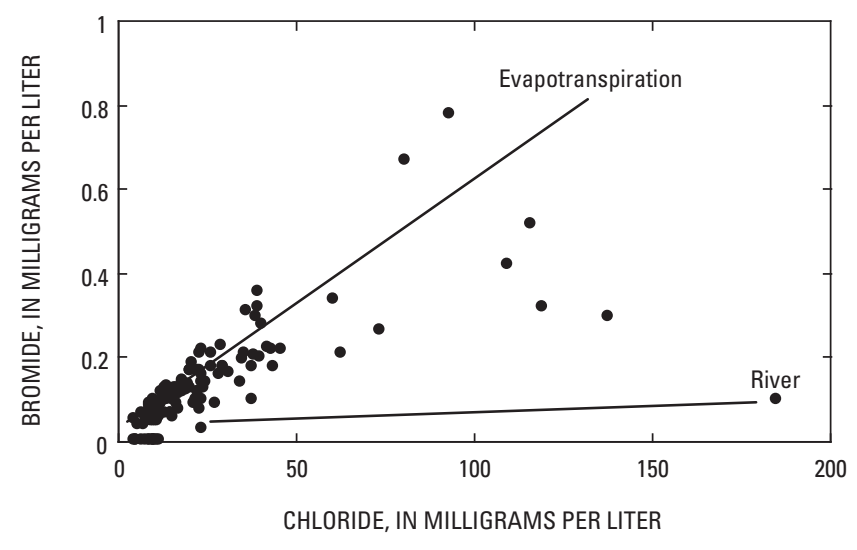

Figure 5. Chloride and bromide concentrations for ground-water samples from wells completed in alluvial aquifer in the Bayou Bartholomew Basin.

\section{Upward Flow of Saline Water from Underlying Formations}

The potential for upward leakage through underlying aquifer systems is based on head relations between the alluvial and underlying aquifer systems plus the presence and permeability of confining layers separating the aquifers. Ackerman (1989) stated that data were insufficient to quantify the flux between the alluvial aquifer and underlying aquifers, but estimated that the flux might be upward in approximately half of the area of the Lower Mississippi River Valley. As such, the possibility of upward flow of water from units underlying the alluvial aquifer must be included as a potential chloride source based on the potential for an upward flux from underlying aquifers.

A comparison of potentiometric-surface maps for the upper Claiborne aquifer (Schrader and Joseph, 2000) and the alluvial aquifer (Schrader, 2001) was made using water levels measured in 2000. For this period of measurement, the potentiometric surface for the upper Claiborne aquifer was consistently lower than the surface of the alluvial aquifer by greater than 20 feet throughout the study area. Because water levels have remained fairly stable in the alluvial aquifer in southeastern Arkansas since the 1950s through the 1990s (Kresse and Huetter, 1999; Kresse and others, 1997), the relation between the upper Claiborne and alluvial aquifer water tables can be assumed to have generally been consistent over the years. However, the Arkansas River has been in its present position for approximately 6,000-7,000 years (Saucier, 1994). Therefore, an assessment of the chemical evolution of ground water in the alluvial aquifer in the study area must assume that directional changes in flux between the potentiometric surfaces of the upper Claiborne and alluvial aquifer are possible outside the period of record for these systems.

In the study area, the underlying upper Claiborne aquifer served in the past as an important domestic water supply. The upper Claiborne aquifer underlies the alluvial aquifer and the two aquifer systems are separated by the VicksburgJackson confining unit. The distribution of wells completed in the upper Claiborne aquifer with corresponding chloride concentrations is shown in figure 6. In Area I, there were 72 ground-water samples with mean and median concentrations of 9.9 and $8.7 \mathrm{mg} / \mathrm{L}$, respectively. Only 2 of the 72 samples had chloride concentrations greater than $20 \mathrm{mg} / \mathrm{L}$. As such, upward flow of saline water from the upper Claiborne aquifer is not likely the source of elevated chloride concentrations in the alluvial aquifer in Area I.

\section{Low Recharge Coupled with Evapotranspiration}

Ground-water levels, soils, and surface geomorphology are important components for evaluating recharge potential and the effects of flushing on ground-water quality. Prior to agricultural development in the study area, much of the land was wet or flooded in backswamp areas, and most of the predevelopment water levels in the alluvial aquifer were less than 20 feet below land surface (Ackerman, 1996). A review of ground-water levels in Desha and Lincoln Counties during the period of 1955 through 1958 revealed 54 wells in Desha County and 64 wells in Lincoln County with water levels less than 10 feet below land surface, and numerous wells with water levels less than 5 feet below land surface. In areas with flooded and water-soaked clay-rich soils, low recharge coupled with evapotranspiration can lead to high salinity.

To investigate potential relations with clay-rich soils, existing GIS data layers for the general geology, geomorphology, soils, and confining-layer thickness maps of the study area were overlain onto and visually compared to chloride concentration distribution. The confining-layer thickness maps 


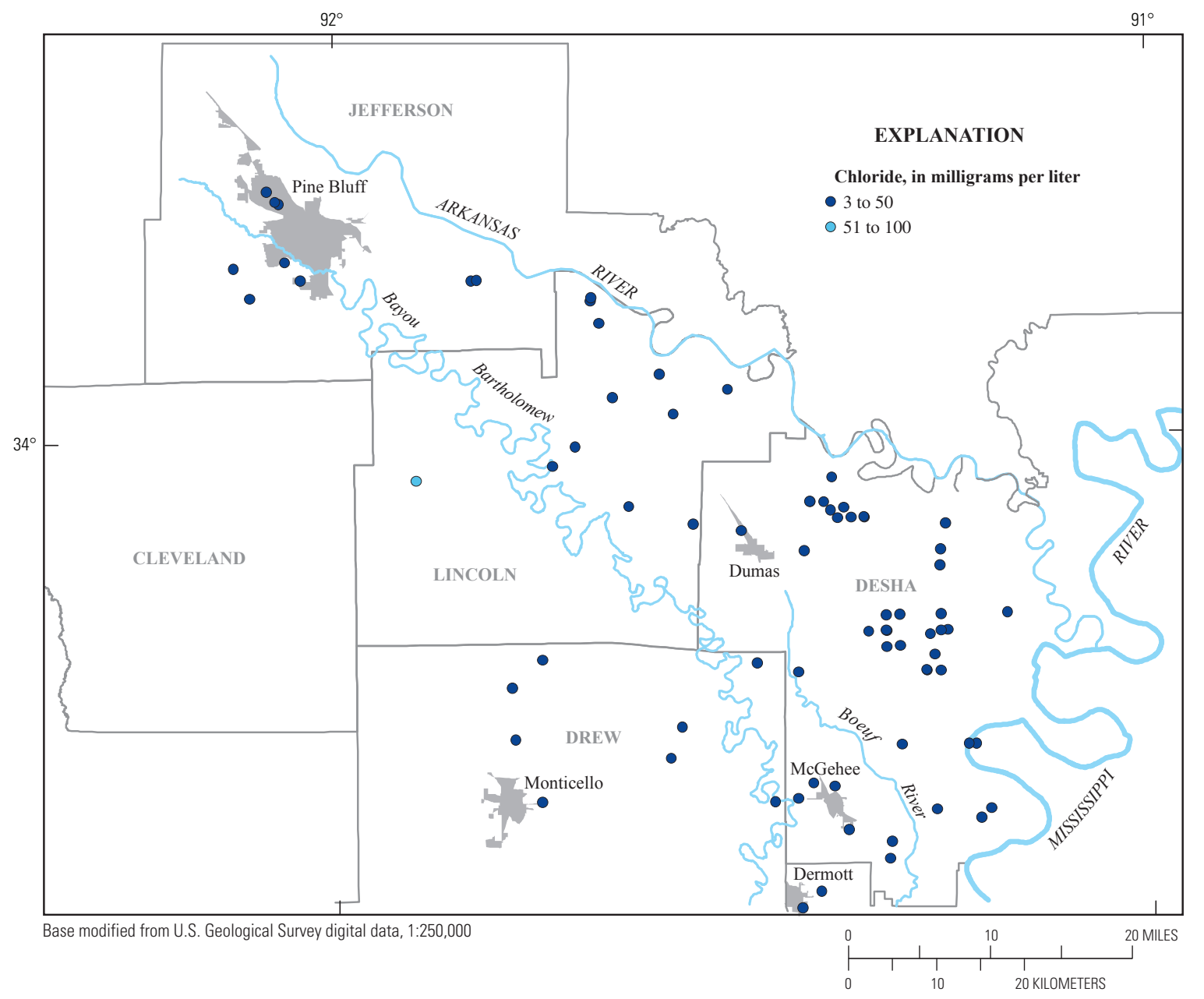

Figure 6. Distribution of chloride concentrations in ground-water samples from wells completed in the Cockfield aquifer in Area I.

were contoured from clay thicknesses compiled from driller's logs (Gonthier and Mahon, 1994). No relation was noted between chloride concentrations and the confining layer thickness contours, however, lack of correlation may be attributed to spatial resolution of the clay thickness map and inaccuracy in the logs rather than lack of influence by confining clays. A comparison of chloride concentrations to the Arkansas geology map shown in figure 2 (Haley, 1976) revealed only a general relation. Most of the elevated chloride concentrations were in areas mapped as Qso deposits; alluvial deposits of local streams or overbank deposits of major streams. However, the range of chloride concentrations varied widely within the area of Qso deposits. Soil maps compiled by the Soil Conservation Service (U.S. Department of Agriculture, Soil Conservation Service, 1972), similar to the general geology, showed only minimal relation of clay-rich soil and elevated chloride concentrations. Much of the area bordering the Arkansas River was mapped as the clay-rich Perry Series soils; however, chloride concentrations were very low in this area.

Saucier (1994) compiled and modified maps of the geomorphology of the surface of the Lower Mississippi Valley, which provide substantial detail of the various landforms within the study area, including Pleistocene valley-train deposits and Holocene channel and backswamp deposits. These maps were used to investigate the relation between the geomorphology and the elevated chloride concentrations in Area I (fig. 7). A good comparison is noted between the distribution of active channel point bar deposits of the Bayou Bartholomew and Arkansas River and the occurrence of low ( $<50 \mathrm{mg} / \mathrm{L}$ ) chloride concentrations. An abandoned channel of an ancient course of the Arkansas River is mapped between the Arkansas River and Bayou Bartholomew, and chloride concentrations also are low in samples from wells completed in these deposits. This is especially apparent in southeastern Jefferson and northwestern Lincoln Counties, where greater concentrations occur in the backswamp deposits to the east and west of the abandoned channel. In Desha County, the abandoned channel divides into two courses; one fork trending east toward the Mississippi River and the other fork trending south toward southern Desha County. Lower chloride concentrations are noted within the east-trending fork of the abandoned channel, with greater concentrations found to the north and south of this fork.

Wilson and others (2000) conducted a water-quality assessment of irrigation wells throughout Desha County with an emphasis on chloride and bicarbonate concentrations 


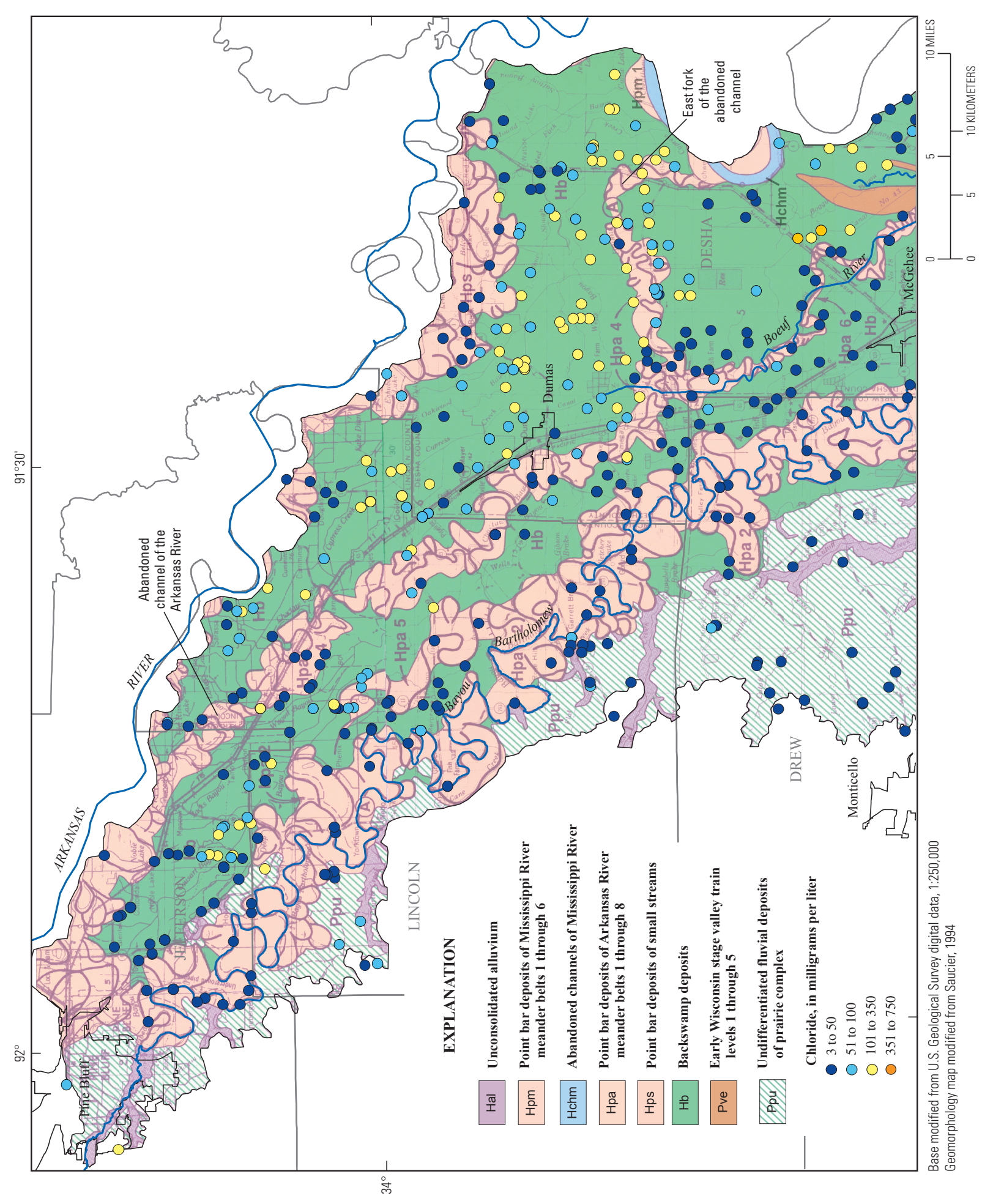


because of those species undesirable effects on crops. Fieldreagent kits were used to measure chloride concentrations in the field. Because no samples were collected for laboratory analysis, no quality-control mechanisms are available to validate the accuracy of the field measurements. However, a visual evaluation of the data from Wilson and others (2000) to the ADEQ and USGS data used for this report revealed a good comparison of the overall distribution of elevated chloride concentrations in the backswamp areas and low concentrations in the channel deposits. The additional data afforded by the much larger data set of Wilson and others (2000) resulted in a much-improved fit with the geomorphology.

Several comparisons are noted in an inspection of the data from Wilson and others (2000) between the geomorphology and the distribution of chloride concentrations (fig. 8). A band of lower chloride concentrations matches extremely well with the channel deposits along the east-trending fork of the abandoned channel mapped by Saucier (1994). North of this fork, there is a gradation of concentrations between the abandoned channel and the Arkansas River with the greatest concentration in the center of the backswamp deposits at the midway point between the two channels. At further distances from the channel deposits, only the finest sediment is transported and deposited, clayey soils reach their maximum thickness (Whitfield, 1975), and recharge should be the lowest relative to surrounding, coarser grain-size, higher-permeability topstratum. A combination of advective flushing and relatively coarser material near to the channel deposits keeps chloride concentrations low in parts of the backswamp deposits closest to the channel deposits. This mechanism is apparent in the area of the backswamp deposits between Bayou Bartholomew and the abandoned channel, where the channel deposits lie in close proximity to one another and the width of the backswamp deposits is narrower. Where the backswamp deposits are larger in extent and the channel deposits are separated by a broader expanse of backswamp deposits, such as between the Arkansas River and the abandoned channel, recharge is minimal, little to no flushing occurs, and ground-water chloride concentrations are the greatest. The fine-grained, clay-rich deposits associated with backswamp areas likely restrict recharge, induce increased ratios between evapotranspiration and recharge, and experience minimal flushing of salts concentrated during evapotranspiration.

Elevated chloride concentrations also are found in southern Desha County within an area mapped as Pleistocene valley train (Pve) deposits (fig. 8). Although soil maps for the area of Pve deposits (U.S. Department of Agriculture, Soil Conservation Service, 1972) show a dominance of clay-sized sediments in this area, there is not a good comparison between lower chloride concentrations in the channel deposits and higher concentrations in the Pve deposits. Elevated chloride concentrations in this area may represent the northern extension of the source of elevated chloride concentrations described in Area II (see section below on potential chloride sources in Area II), and not representative of processes described for Area I. Although different sources are noted for Area I and
Area II, there does not appear to be a well-defined boundary between the two areas.

\section{Estimation of Recharge Rates from Chloride Concentrations in Area I}

Evaporation and transpiration act to concentrate solutes as recharge moves from the surface through the root zone of soils. Chloride concentrations in ground water relative to those in rainwater frequently have been used to estimate recharge in areas where recharge is difficult to measure by other methods (Allison and Hughes, 1978; Sharma and Hughes, 1985). Kresse and Fazio (2002) used the chloride mass balance (CMB) method to estimate a recharge rate of $3 \mathrm{in} / \mathrm{yr}$ in Woodruff County, Arkansas, which compared well to published values for eastern Arkansas (Mahon and Ludwig, 1990; Bedinger and Jeffery, 1964). The CMB method using equation 1 was employed to evaluate the potential recharge rates necessary to increase chloride concentrations in Area I.

Data for chloride concentrations in precipitation were taken from the National Atmospheric Deposition Program (2008) and averaged over a 20-year period from 1985 to 2005, resulting in a mean concentration of $0.25 \mathrm{mg} / \mathrm{L}$. Dry fallout is not measured in Arkansas, but is an important component of chloride input to the system. To account for dry fallout, the average concentration in rainfall was increased by a factor of two (Appelo and Postma, 1999; Oberg, 2003; Scanlon and others, 2003), doubling the precipitation concentration to 0.50 $\mathrm{mg} / \mathrm{L}$. A maximum of $360 \mathrm{mg} / \mathrm{L}$ chloride was used to represent the greatest ground-water concentration in Area I ground water, and $50 \mathrm{in} / \mathrm{yr}$ as the annual mean precipitation in Arkansas (Freiwald, 1984). Using these figures resulted in a recharge rate of $0.07 \mathrm{in} / \mathrm{yr}$ or 0.14 percent of the average precipitation. Chloride concentrations greater than $300 \mathrm{mg} / \mathrm{L}$ only occur in small areas of Desha County, and, as such, this low recharge rate represents a theoretical point recharge rate for small areas representative of lower permeability surficial deposits that are more conducive to generation of greater salinity values because of high evapotranspiration/recharge ratios.

Although such low rates of recharge have been documented in arid and semi-arid environments (Prych, 1995; Macfarlane and others, 2000; Orr and others, 2002; Shurbaji and Campbell, 1997; Scanlon, 1991), these values are somewhat low for Arkansas, considering the State's relatively large amount of precipitation, and the values are at the extreme low end of regional recharge rates listed for humid areas of the United States (Delin and Risser, 2007). However, the low value representing areas with elevated chlorides for this study represent a localized recharge estimate that is not representative of basin-scale recharge rates, in addition to using only one method (CMB). Delin and Risser (2007) listed numerous factors that influence the spatial variability of local recharge including soil properties, vegetative cover, land use, topography, water content of surface materials, confining layer depth, and climatic conditions. They also noted that low-permeability 


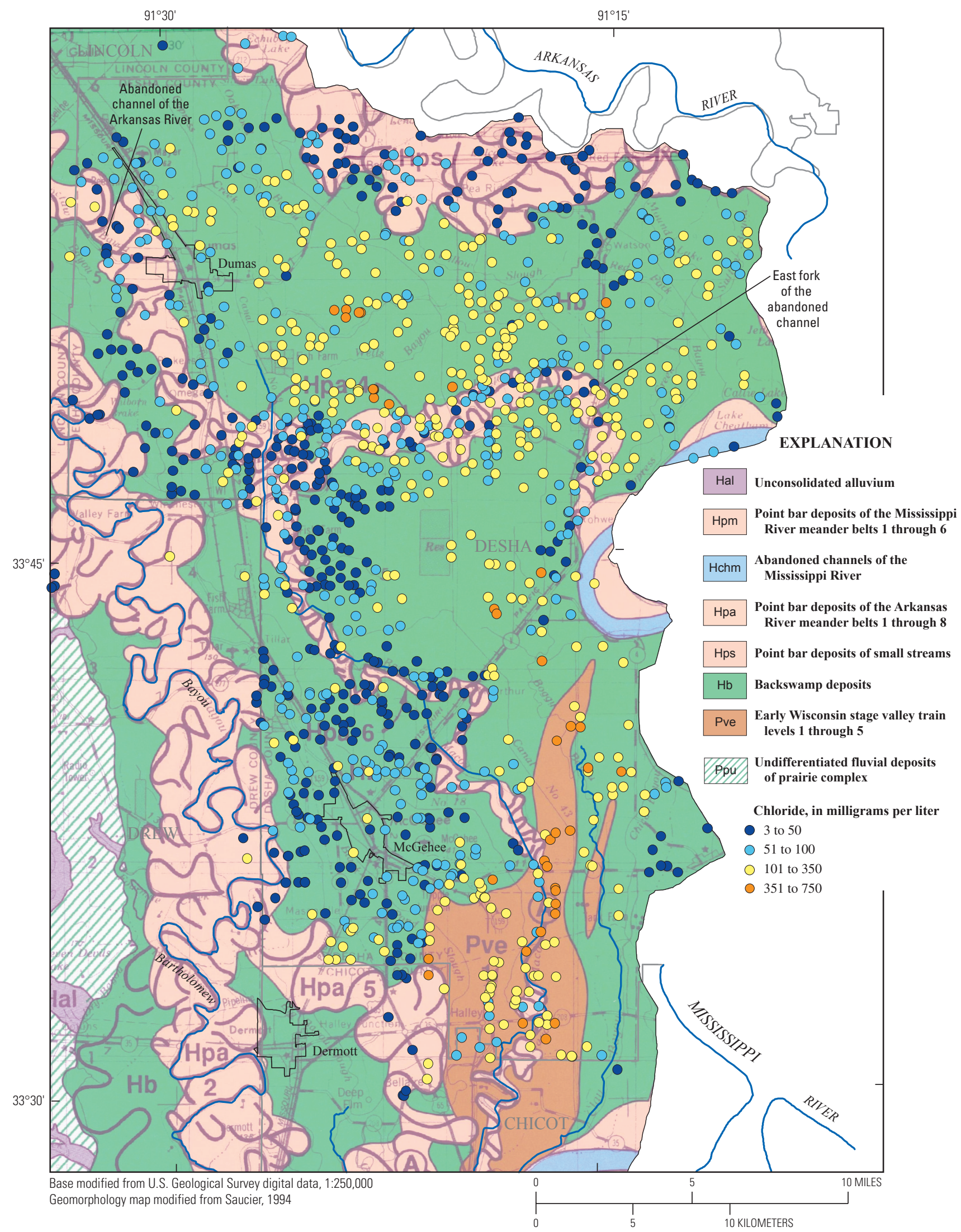

Figure 8. Distribution of chloride concentrations in ground-water samples from wells completed in the alluvial aquifer in Area I overlain onto a map of Quaternary geomorphological landforms (from Wilson and others, 2000). 
layers at the surface coupled to evapotranspiration effects in areas of shallow ground water, similar to conditions in Area I, can greatly reduce estimated local-scale recharge rates, which are of limited use in basin- or regional-scale recharge.

Stanton and Clark (2003) used four recharge rates for recalibration of a ground-water flow model of the alluvial aquifer in southeastern Arkansas, with values ranging from $0.83 \mathrm{in} / \mathrm{yr}$ to $2.5 \mathrm{in} / \mathrm{yr}$; however, these rates were based on general geology and soil distribution for use in a ground-water flow model, with the four average rates divided over the entire area. As such, the lower value of $0.83 \mathrm{in} / \mathrm{yr}$ integrated recharge over a large area, which included backswamp and channel deposits and did not account for local, small-scale variation of soil type and recharge rates. The lowest chloride concentration of $3.2 \mathrm{mg} / \mathrm{L}$ for Area I results in an estimated high-end recharge rate of $7.81 \mathrm{in} / \mathrm{yr}$. As such, both the low and high concentrations theoretically represent the variation of localized effects of soil type, climatic effects, and evapotranspiration, and bracket the range of estimated recharge rates of Stanton and Clark (2003). The median chloride concentration of 36.5 $\mathrm{mg} / \mathrm{L}$ for Area I equates to a estimated recharge rate of 0.68 in/yr using the CMB method, which compares well with the lowest recharge rate of $0.83 \mathrm{in} / \mathrm{yr}$ used in the model for Stanton and Clark (20003) for areas with clayey topstratum.

Prior to development, the natural-drainage network in the backswamp areas was inefficient, flooding was frequent, and the area was dominated by lush wetland forests (Broom and Reed, 1973). The deep root system associated with wetland forest coupled with poorly drained soils would tend to uptake and transpire a large proportion of the small flux of shallow recharge, causing an increase in chloride concentrations. Soils in the backswamp areas are listed as Perry Series, which consists of poorly drained, very low permeability soils formed in beds of clayey alluvium (U.S. Department of Agriculture, Soil Conservation Service, 1972). These soils were formed on level, broad flats or in depressions and have slopes of $0-1$ percent. These areas tend to be somewhat stagnant with little flushing by ground water from surrounding high-recharge, channel deposit areas. The existence of this situation is supported by past alluvial aquifer potentiometric-surface maps (Bedinger and Reed, 1961; Broom and Reed, 1973) prior to large-scale pumping for agriculture and more recent investigations (Schrader, 2001; Reed, 2004), which all show flow into the backswamp areas from the area of channel deposits of Arkansas River to the north and Bayou Bartholomew to the southwest.

Because the water-quality samples for this study were collected from irrigation wells, which tap the most productive sands and gravels at the base of the alluvial aquifer, little information is available in regard to the quality of water in the upper part of the saturated zone and especially in the unsaturated zone. Shurbaji and Campbell (1997) stated that piston flow is assumed for equation 1 and where flow is impeded by low-permeability zones coupled with large uptake of water in the root zone, that flow to ground water will represent preferential flow through macropores and diffusive-scale movement in more stagnant zones. They noted a bimodal distribution of chloride concentrations with a maximum of $1,836 \mathrm{mg} / \mathrm{L}$ at 6 feet below land surface as a result of transpiration processes in the root zone, despite approximately $15 \mathrm{in} / \mathrm{yr}$ of precipitation, and a concentration of $250 \mathrm{mg} / \mathrm{L}$ below the root zone. The geochemistry of water in the lower part of the saturated zone in Area I possibly represents a combination of focused-flow water of low chloride concentration through macropore structures during periods of high rainfall and slowly drained water with elevated chloride concentrations from low-permeability clay-rich zones.

Site-specific field studies are necessary to validate the low recharge rates calculated from the CMB method for areas of elevated chlorides in Area I. The use of tracers, including isotopes of oxygen and hydrogen and other geochemical data, has proven invaluable in delineating evaporation fronts and age-dating of recharge water (for example, Sharma and Hughes, 1985; Shurbaji and Campbell, 1997; Allison and Hughes, 1978). This type of information would be integral to substantiating mechanisms and time-scales responsible for the occurrence of saline water, the vertical distribution of chloride related to soil texture and type, and the potential for inducing spreading of elevated chloride concentrations into surrounding areas for Area I. This information would directly assist the agricultural community and water-management agencies by identifying optimum areas for production of high-quality water.

\section{Potential Chloride Sources in Area II}

The alluvial aquifer in Area II contains a relatively narrow, north-south trending band of elevated chloride concentrations with a maximum chloride concentration of $1,639 \mathrm{mg} / \mathrm{L}$ (fig. 9). The occurrence of high salinity water in the Quaternary deposits in Chicot County (Area II) was first documented by Onellion and Criner (1955), and subsequent investigations (Fitzpatrick, 1985: Huff and Bonck, 1993; Kresse and others, 2000) have sought to delineate the extent and magnitude of the elevated chloride concentrations as well as potential sources. Several sources for the high salinity in Area II have been proposed in previous investigations and can be summarized as follows:

1. Upward leakage of saline water from underlying Tertiary aquifer system,

2. Encroachment of saline water through abandoned oil exploration wells, and

3. Movement of water along faults extending into deep, brine-producing formations.

\section{Upward Leakage of Saline Water from Underlying Tertiary Formations}

Early reports of saline water encountered by wells completed in the upper and middle Claiborne aquifers in Chicot County led researchers to hypothesize that water in 


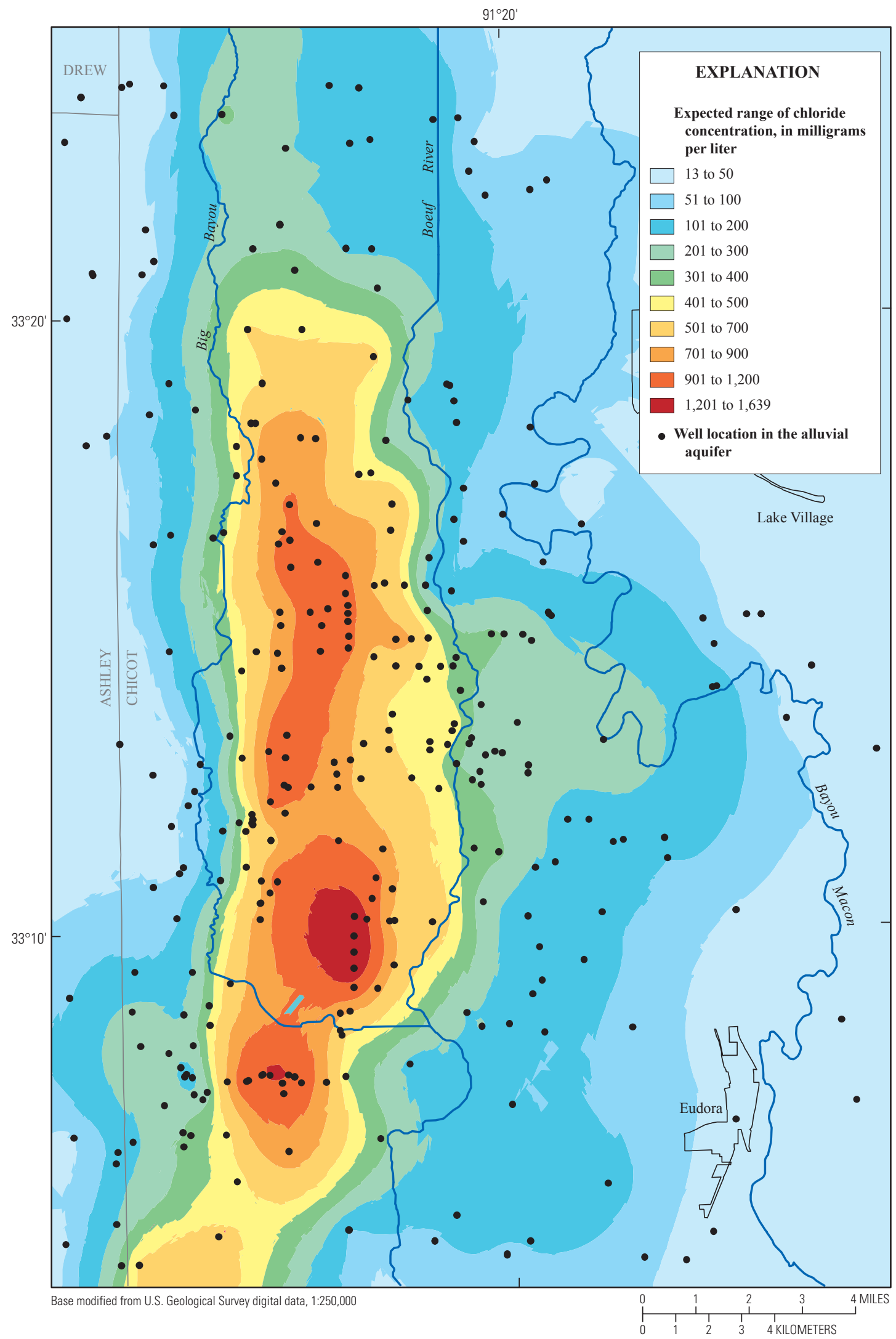

Figure 9. Distribution of alluvial aquifer chloride concentrations in Area II. 
these Tertiary formations becomes mineralized with increased residence time along the flow path, and that leakage through thinning intervals of the Vicksburg-Jackson confining unit was a potential source for the elevated chloride concentrations in the alluvial aquifer in Area II (Onellion and Criner, 1955; Fitzpatrick, 1985). Payne (1968) used resistivity and spontaneous potential logs from oil and gas wells to delineate a boundary between fresh and saltwater for the middle Claiborne aquifer and showed that the aquifer was saline throughout most of Chicot County. However, Kresse and others (2000) showed that chloride concentrations ( $380 \mathrm{mg} / \mathrm{L}$ and $385 \mathrm{mg} / \mathrm{L}$ ) in two wells completed in the upper Claiborne aquifer in the zone of elevated chloride concentrations in Area II were approximately half of that recorded in two nearby alluvial wells (750 $\mathrm{mg} / \mathrm{L}$ and $850 \mathrm{mg} / \mathrm{L}$ ). Additionally, ground-water samples from two wells completed in the upper Claiborne aquifer in Eudora, Arkansas, east of Area II, had chloride concentrations less than $100 \mathrm{mg} / \mathrm{L}$ (Onellion and Criner, 1955). A review of well logs showed thicknesses greater than 100 feet for the Jackson Group in the zone of elevated chloride concentrations in Area II. As such, geologic and water-quality data posed doubts in regard to the potential for upward flow from Tertiary aquifers as a viable potential source for the elevated chloride concentrations in the alluvial aquifer.

To test the hypothesis of upward flow, as a part of a previous study (Kresse and others, 2000), five monitoring wells were completed in the upper Claiborne aquifer and one well completed in the middle Claiborne aquifer along two east-west transects of the zone of elevated chloride concentrations in Area II. Twenty-one domestic wells completed in the upper Claiborne aquifer also were identified and sampled for that study. Chloride concentrations in ground-water samples from these wells were used to construct an isoconcentration map of chloride concentrations in the upper Claiborne aquifer, and this map was superimposed onto the shaded-contour map of chloride concentrations in the alluvial aquifer for comparison (fig. 10). The resulting map is remarkably similar to that of the alluvial aquifer shaded-contour map; elevated chloride concentrations in an elongated north-south band, decreasing concentrations to the east and west of the zone of elevated chloride concentrations, a sharper gradient to the west, and spreading to the east of chloride concentrations from 100-300 $\mathrm{mg} / \mathrm{L}$. This spatial relation would suggest a deeper source of saline water, which affects the overlying upper Claiborne and alluvial aquifers.

A review was conducted of chloride concentrations in wells completed in the middle Claiborne aquifer for comparison to the zone of elevated chloride concentrations in the alluvial aquifer. Wells completed in the middle Claiborne aquifer were too few to construct an accurate isoconcentration map for this aquifer system. Chloride concentrations in samples from three wells completed in the middle Claiborne aquifer and one well completed in the underlying lower Claiborne aquifer are shown in figure 11. A water sample from the monitoring well installed in the middle Claiborne aquifer beneath the zone of greatest alluvial aquifer chloride concentrations yielded a chlo- ride concentration of $2,646 \mathrm{mg} / \mathrm{L}$. However, a well completed in the middle Claiborne aquifer near Lake Village, Arkansas, east of the zone of elevated chloride concentrations had a chloride concentration of only $171 \mathrm{mg} / \mathrm{L}$, which indicates that the occurrence of saline water in the middle Claiborne aquifer is of limited extent and that chloride concentrations decrease in the middle Claiborne aquifer east of the zone of elevated chloride concentrations. A ground-water sample from a well in the lower Claiborne aquifer, east of the middle Claiborne aquifer monitoring well, contained a chloride concentration of $838 \mathrm{mg} / \mathrm{L}$. Because the lower Claiborne aquifer underlies the middle Claiborne aquifer and should contain a greater salt content if salinity increases with depth and increased residence time along the flow path, the lower chloride concentration in the well completed in the lower Claiborne aquifer does not support an increasing chloride concentration in the downgradient (eastward) direction of flow. Kresse and others (2000) compared water levels for three wells at one aquaculture farm; each completed in the alluvial, Cockfield, and Sparta aquifers and drilled within 100 feet of one another. The hydraulic gradient was downward in all three formations, which provides some additional information that upwelling of saline water from the middle Claiborne aquifer is not the source of saline water, and that a deeper source affects the alluvial and Claiborne aquifer systems.

Huff and Bonck (1993) reviewed the occurrence of saline water in shallow aquifers in east-central and northeastern Louisiana and in southern Arkansas, and ruled out underlying Tertiary aquifers as the source of saline water in the alluvial aquifer. They used bromide/chloride ratios in water samples from the alluvial aquifer, Tertiary aquifers, and samples of brine water from the Jurassic Smackover Formation to develop mixing curves and investigate sources of saltwater within the alluvial aquifer. Results from the study discounted upward flow of saline water from underlying Tertiary aquifers as a potential mechanism for salinity in the alluvial aquifer in Area II, because of the lack of correlation in the geochemically distinct bromide/chloride ratios observed in water samples. The general trend of chloride concentrations in the upper and lower Claiborne aquifers, together with the mixing curves developed from bromide/chloride ratios (Huff and Bonck, 1993), indicates that a deeper source of saline water is affecting these aquifer systems, in addition to affecting the alluvial aquifer in Area II.

\section{Encroachment of Saline Water through Abandoned Oil Exploration Wells}

The distribution, dates of drilling, and other pertinent information related to oil exploration wells was investigated to assess the potential for these wells as a source of the saline water in Area II. A review of information on oil exploration wells in Chicot County revealed that most of these wells were drilled from 1960 to 1980, after the documentation of elevated chloride concentrations in samples collected from the alluvial 


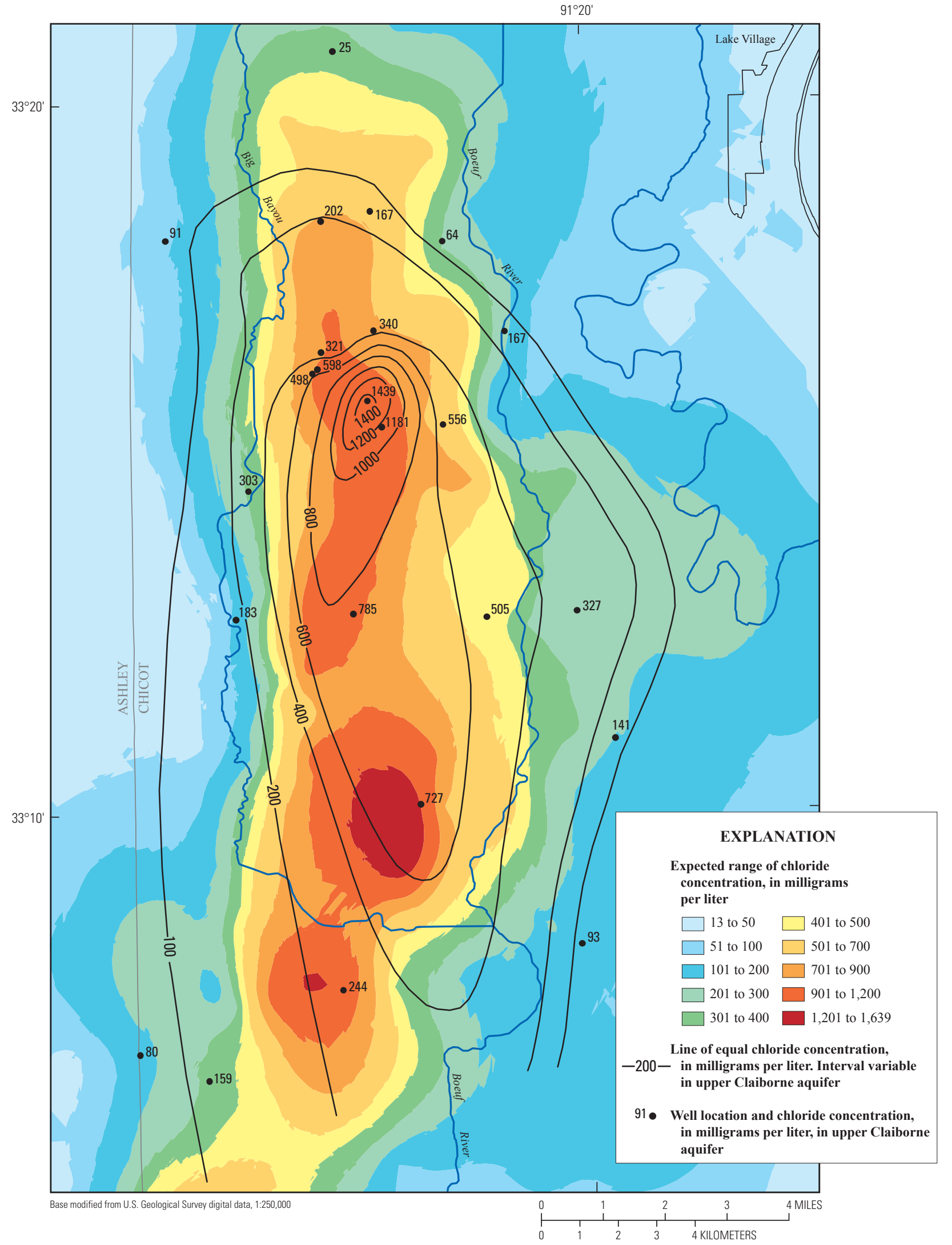

Figure 10. Chloride isoconcentration contours for ground-water samples from wells completed in the upper Claiborne aquifer in Area II overlain on a shaded contour map of chloride concentrations in the alluvial aquifer. 


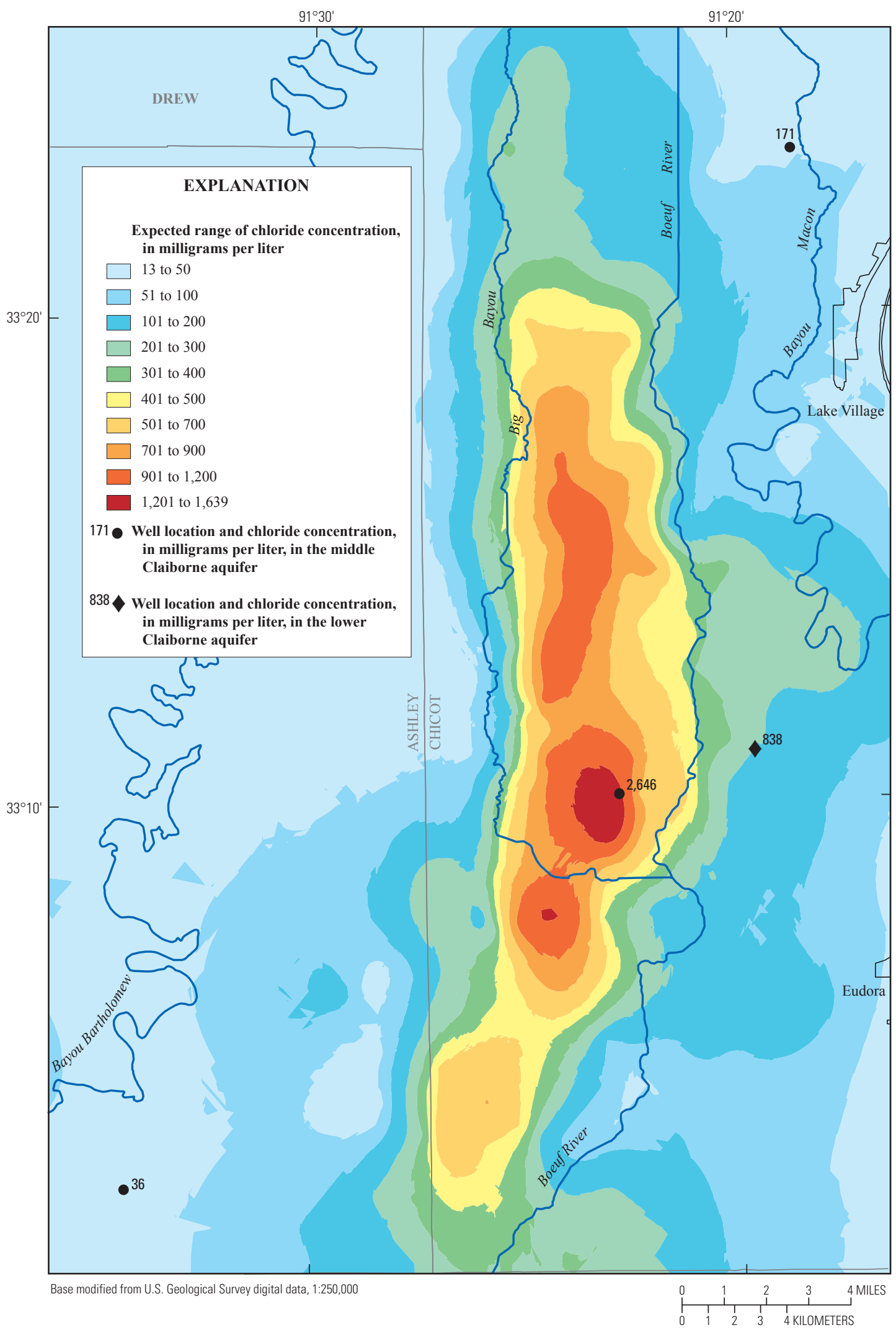

Figure 11. Chloride concentrations in ground-water samples from three wells completed in the middle Claiborne aquifer and one well completed in the lower Claiborne aquifer in Area II overlain on a shaded contour map of chloride concentrations in the alluvial aquifer. 
aquifer in 1952 to 1953 (Onellion and Criner, 1955). One exploration well drilled in 1944 was located near the southern edge of the zone of elevated chloride in Area II, and chloride concentrations from alluvial wells in the vicinity of this well were considerably lower than the maximum chloride concentrations (Kresse and others, 2000). Fitzpatrick (1985) cited one exploration well as a potential source, but noted that the chloride concentration $(800 \mathrm{mg} / \mathrm{L})$ in an alluvial well drilled next to this well was considerably less than the maximum concentration $(1,360 \mathrm{mg} / \mathrm{L})$ in an alluvial well to the north of this well. Veatch (1906) reported on general water quality in southern Arkansas and northern Louisiana; however, water quality was only addressed in qualitative statements, such as chalybeate (iron-rich), sulphur, hard, and salty water. He listed the occurrence of "salty" water in a horizon 800-1,000 feet deep in northern Moorehouse Parrish and in West Carroll Parrish in northern Louisiana, immediately south of Chicot County. The zone of elevated chloride concentrations in Area II in this report is contiguous with and extends into northern Louisiana and each area was associated with the same source (Huff and Bonck, 1993), and a well completed 800-1,000 feet deep would be completed in the Claiborne aquifer system. As such, the occurrence of saline water in the well-water samples from the Claiborne aquifer from wells completed prior to 1900 would tend to discount encroachment through abandoned oil and gas wells.

\section{Movement of Water along Faults Extending into Deep, Brine-Producing Formations}

The elongated nature of the zone of elevated chloride concentrations in Area II has been noted by investigators as suggesting a line source or linear conduit connection with the source, rather than a point source of contamination (Fitzpatrick, 1985; Huff and Bonck, 1993). Fitzpatrick (1985) proposed that the likely avenue for the line source was along a fault or movement through the Vicksburg-Jackson confining unit, where thinned through erosion processes. The only evidence for any faulting, however, was a northwest-southeast trending fault mapped in Ashley County (Hewitt and others, 1949) to the west of the zone of elevated chloride concentrations. Huff and Bonck (1993) alluded to the intersection of two wrench faults in the vicinity of Area II as mapped by Zimmerman (1992). Zimmerman (1992) mapped a fractured limestone in the Jurassic Smackover Formation in Arkansas, Mississippi, and Louisiana for the purpose of hydrocarbon exploration. The mapped faults and the intersection of these faults in the study area are shown in figure 12. Zimmerman (1992) stated that at least one of the faults extended into the Smackover Formation and had been active as late as the Pleistocene or Holocene Periods. As such, upward movement of briny water in the Smackover Formation along these faults in southern Chicot County could introduce saline water into the alluvial aquifer (Huff and Bonck, 1993).

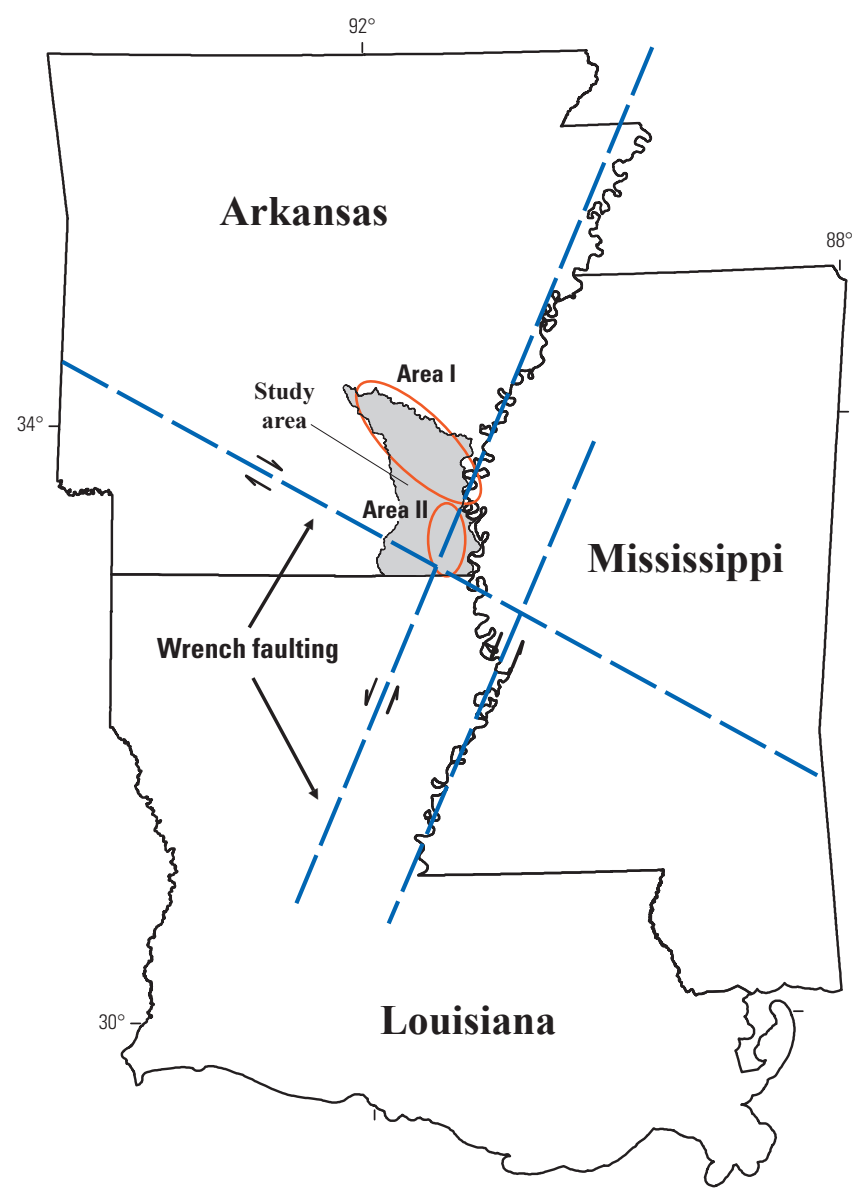

Base modified from U.S. Geological Survey digital data, 1:250,000

Modified from Zimmerman, 1992

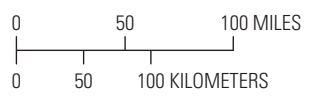

Figure 12. Proposed zones of wrench faulting in the Jurassic Smackover Formation.

The distribution and spreading of saline water contamination in Area II has been of great interest to researchers not only from a standpoint of predicting sources (line source or point source), but also from the viewpoint of processes or hydrogeologic framework characteristics responsible for limiting east-west spreading of the zone of elevated chloride concentrations. Huff and Bonck (1993) used maps from earlier investigations (Saucier, 1967) to identify paleotopographic features on top of the Cockfield Formation. They stated that elevated concentrations of chloride and total dissolved solids plotted along the surface of a buried channel defined at the contact of the alluvial deposits and the top of the Cockfield Formation. However, no mention was made of the Jackson Group, which serves as a confining layer between the Cockfield Formation and the Quaternary deposits, and reaches thicknesses ranging from 80 to 100 feet. Invoking a buried-channel theory for inducing density driven flow of saltwater along this channel would necessitate a similar channel on the surface of the Jackson Group. 
Kresse and others (2000) showed that the zone of elevated chloride concentrations was situated between Big Bayou and the Boeuf River, and proposed that these streams may exert hydraulic control on ground-water movement in the area, serving as flow boundaries or divides. Broom and Reed (1973) showed a gaining ground-water condition for most of the reaches of Big Bayou and Boeuf River in Chicot County during the fall and spring of 1970, which indicates possible hydraulic control on movement of ground water in the saline water plume. Ground-water flow into Big Bayou only was shown in the northern part of Chicot County, whereas groundwater flow into the Boeuf River was throughout Chicot County. A potentiometric-surface map determined from water levels measured in approximately 100 wells during the winter of 2001 was constructed and superimposed on a chloride concentration shaded contour map (fig. 13). Flow lines indicated that Big Bayou is neither gaining nor losing, whereas Boeuf River is gaining throughout most its reach in Area II. Groundwater flow directions do not appear to impose constraints upon the distribution of chloride concentrations; spreading to the east occurs, although the Boeuf River acts as a hydraulic boundary, and little to no spreading occurs to the west, though Big Bayou has no influence on ground-water flow lines. One comparison that is noted is that the band of greatest chloride concentrations is in the area of highest ground-water levels. The area of high ground-water levels curves to the southwest, similar to the band of elevated chloride concentrations.

Because the direction of ground-water flow in Area II did not appear to control the elongated shape of the distribution of chloride concentrations, the influence of stratigraphy was investigated by superimposing the chloride concentrations on a geomorphology map (fig. 14). Similar to the potentiometricsurface map, the bending of the band of elevated chloride concentrations follows the bend of an abandoned channel of the Arkansas River. Recharge has been shown to be highest in the channel deposits (Bedinger and Reed, 1961; Bedinger and Jeffery, 1964), which is supported by figures 13 and 14; the greatest ground-water elevations generally align with the occurrence of channel deposits. Rather than hydraulic influences, the shape and distribution of the zone of elevated chloride concentrations may be influenced by density controlled transport along channels developed by geologic and geomorphologic processes.

\section{Evaluation of Temporal Trends in Chloride Concentration and Distribution}

An evaluation of temporal water-quality trends in southeastern Arkansas is limited to a regional-scale analysis, because of the lack of an adequate database incorporating multiple data points for individual sites. Most of the investigations referenced in this study evaluated general water quality on a regional basis as a resource for municipal, agricultural, and industrial uses. As such, sites were sampled on a one-time basis. Of the approximately 400 wells in the USGS National Water Information System database with samples collected from 1946 to 1959 , only 15 were resampled in subsequent years, and these 15 sites show no consistent temporal trends. Additionally, small-scale spatial variation in ground-water geochemistry has been documented in the alluvial aquifer and limits the use of comparing nearby wells for assessing temporal trends (Steele and others, 2003). In spite of these limitations, data used for this study included a complete chemical suite of inorganic constituents, including chloride, and were spatially distributed on a scale useful for delineating areas of high- and low-chloride concentrations. As such, comparisons of historic data sets on a regional scale can be made through the use of mean concentrations in a given area and a visual evaluation of the spreading through time of zones of elevated chloride concentrations into regions previously dominated by low chloride concentrations.

\section{Evaluation of Temporal Trends in Area I}

County-level temporal comparisons of mean chloride concentrations in parts of Area I indicate that chloride concentrations have changed little since about 1950. Kresse and others (1997) noted similarities between general water quality collected in 1996 and that of previous investigations dating back to 1948 (Klein and others, 1950; Bedinger and Reed, 1961). Ground-water samples collected for the investigation in Jefferson County in 1996 had a mean chloride concentration of $35 \mathrm{mg} / \mathrm{L}$ (Kresse and others, 1997) compared to a mean concentration of $39 \mathrm{mg} / \mathrm{L}$ for samples collected in 1948-1949 (Klein and others, 1950). In Desha County, the mean chloride concentration for samples collected in 1996 (Kresse and others, 1997) was $62 \mathrm{mg} / \mathrm{L}$ compared to a mean concentration of $56 \mathrm{mg} / \mathrm{L}$ for samples collected in 1952 (Bedinger and Reed, 1961). A chloride isoconcentration map for parts of Lincoln and Desha Counties from Klein and others (1950) revealed a good comparison to a map produced from the 1996 data for the same region (Kresse and others, 1997). Based on the similarity in mean concentrations for total dissolved solids and major ions and the comparison of the spatial distribution of chloride concentrations from the isoconcentration maps for Desha County, Kresse and others (1997) suggested that chloride concentrations had changed little since the early 1950s.

Chloride concentrations for data collected prior to 1960 (1946-1959) were compared to data collected after 1980 (greater than 75 percent of samples collected after 1995) to inspect for spatial differences that might indicate temporal trends (fig. 15). There is a strong similarity between both maps for the occurrence of greater concentrations in the backswamp deposits and the lower concentrations in the active and abandoned channel point bar deposits. There are several attributes that explain the lack of variance over time in the overall distribution and concentration of chloride concentrations in Area 


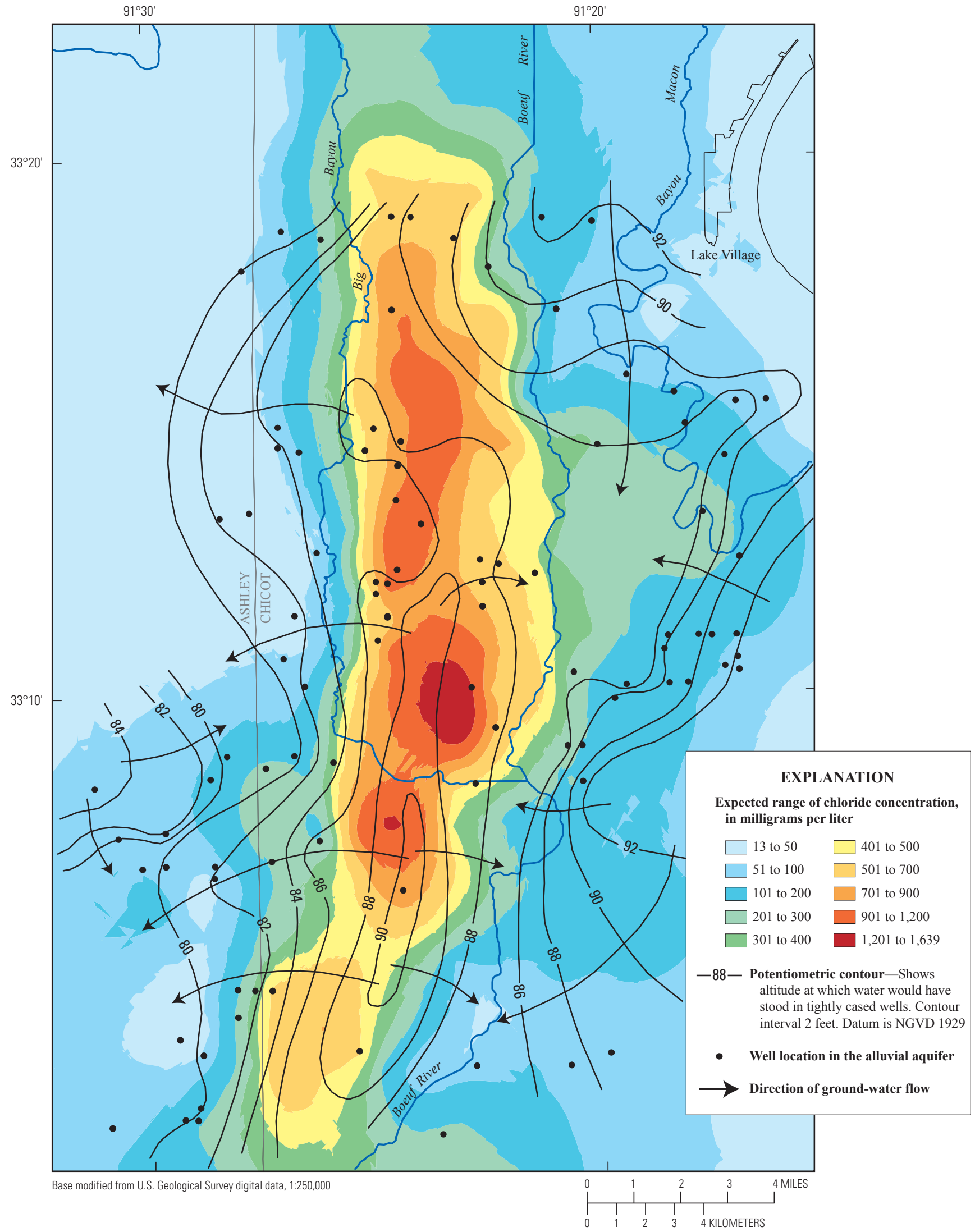

Figure 13. Potentiometric surface of water levels taken from wells in the alluvial aquifer in the winter of 2001 overlain on a chloride concentration shaded contour map. 


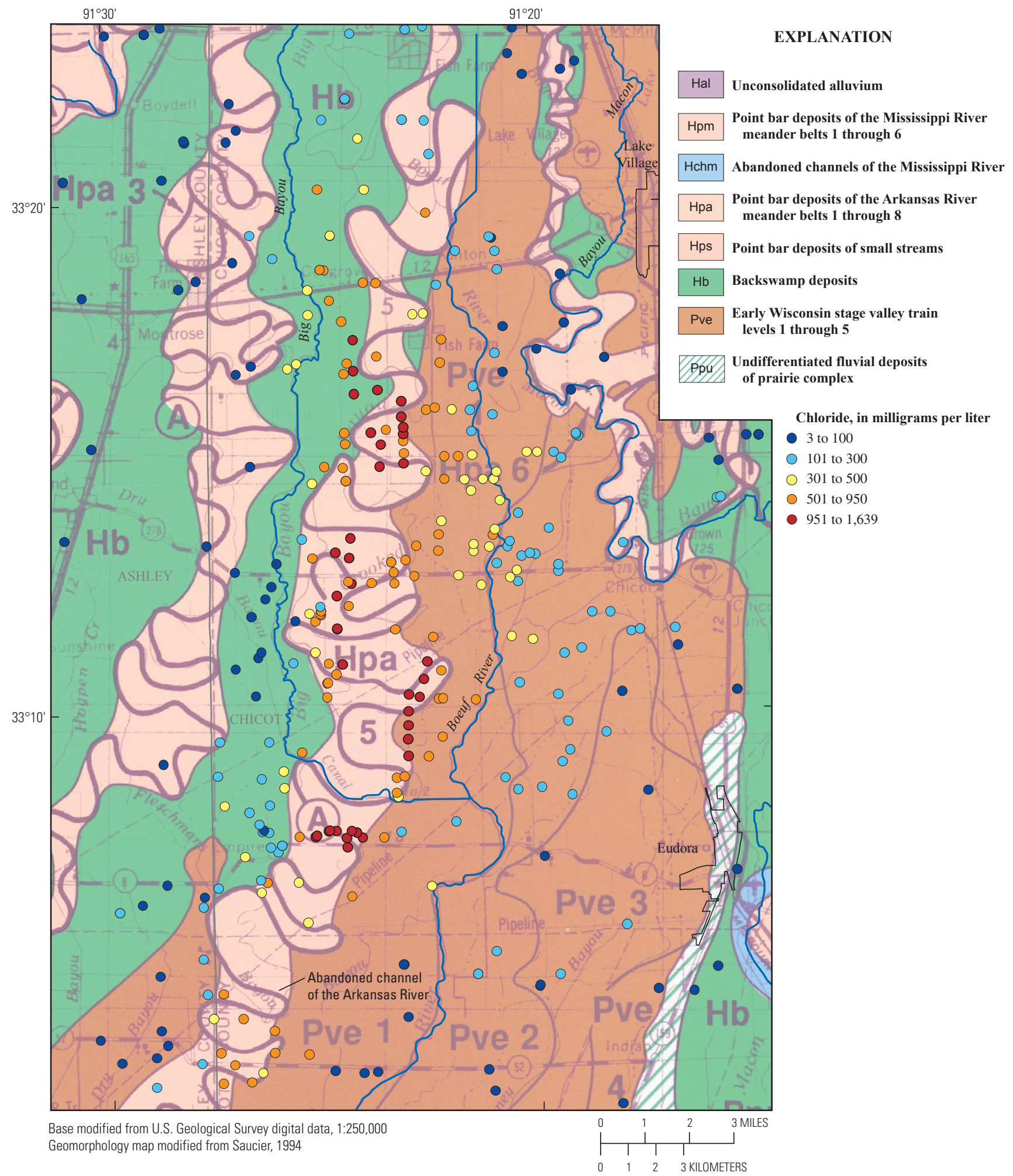

Figure 14. Distribution of chloride concentrations from wells in the alluvial aquifer in Area II overlain on a map of geomorphological landforms. 
I. Ground-water velocities are relatively low (approximately $0.25 \mathrm{ft} / \mathrm{d}$ ), reflecting the flat-lying topography in the area and the related low-gradient water-table surface, and water levels have remained relatively consistent with time (Kresse and others, 1997; Kresse and Huetter, 1999). Although irrigation serves as a major source of ground-water withdrawal in the area, water-level declines in the area tend to be restricted to cones of depression centered on individual wells with drawdowns greater than 2 feet generally expanding to a radius of less than 1 mile during the summer irrigation season; these water levels rebound to prepumping levels by the following spring. Changes from induced flow into pumping wells have not resulted in regional cones of depression or notable changes in water levels over time. Because predevelopment surface hydrology of the area has undergone dramatic changes with the transition to agricultural land use, including deforestation, installation of drainage canals, tillage, land-leveling and other activities, a great potential has been established for changing the vertical flow dynamics and geochemistry over time. However, considering the low rates of physiochemical fluxes of ground water, these changes may be on decadal or larger timescales. This interpretation is based on continued sustainable pumping rates and precipitation at current levels; drastic changes including increased pumping or long periods of drought could result in changes perceived at shorter timeframes.

\section{Evaluation of Temporal Trends in Area II}

Three primary datasets are available for evaluating temporal trends in Area II: Onellion and Criner (1955), Fitzpatrick (1985), and Kresse and others (2000). Onellion and Criner (1955) collected 60 samples during 1952-1953 in two main areas of Chicot County; the northwestern part, which includes a large area of low $(<50 \mathrm{mg} / \mathrm{L})$ chloride concentrations, and an east-west trending line of samples west of Eudora, Arkansas, along Highway 8 (fig. 16), showing elevated chloride concentrations with a maximum concentration of $1,490 \mathrm{mg} / \mathrm{L}$. These areas represent a very small part of the zone of elevated chloride concentrations in Area II, and provide very few data and limited spatial distribution for comparison to later datasets. Fitzpatrick (1985) collected 89 samples in Chicot County from 1982 to 1984, providing a data set with a better spatial distribution, and was the first to delineate both the north-south extent of the zone of elevated chloride concentrations and the degree of spreading to the east and west. A maximum chloride concentration of $1,360 \mathrm{mg} / \mathrm{L}$ was noted in the same area as the maximum concentration in Onellion and Criner (1955). Data from ADEQ collected for the investigation described by Kresse and others (2000) during the summer of 2001 included 217 sampling sites, which were located in the immediate area of the zone of elevated chloride concentrations depicted in Fitzpatrick (1985), and provides the best overall geographical distribution of chloride concentrations in the area to date.
Data from Onellion and Criner (1955) and Fitzpatrick (1985) were used to represent an early (1950-1984) period for comparison to the ADEQ 2001 data set (fig. 16). The earlier data are represented by triangles and the later data by circles, with the same graduated color symbology for similar ranges in concentration. These data generally show close agreement of both data sets. The area containing the greatest chloride concentrations from the 2001 dataset were from wells in the central part of the area between Highways 8 and 160. Two samples collected in this area had chloride concentrations that exceeded $1,600 \mathrm{mg} / \mathrm{L}$ with a maximum of $1,639 \mathrm{mg} / \mathrm{L}$, and six nearby wells had chloride concentrations exceeding $1,000 \mathrm{mg} / \mathrm{L}$. These wells were drilled to supply fish ponds and were not available prior to 1990 . The discovery of this area appeared to shift the area of greatest concentrations to the north, although this merely is a result of the additional wells available for the 2001 sampling period. Conversely, the area of greatest chloride concentrations in the early dataset (1950-1984) was along Highway 8, east of Eudora, Arkansas; however, most of these wells were for domestic supply and are no longer in operation. Six of the wells (depicted as red triangles on figure 16) in this area had concentrations greater than $1,000 \mathrm{mg} / \mathrm{L}$, with a maximum concentration of 1,490 $\mathrm{mg} / \mathrm{L}$, and none of these wells were in operation in 2000 . Two wells sampled in this area in 2001 and near the original six wells had concentrations of $974 \mathrm{mg} / \mathrm{L}$ and $1,078 \mathrm{mg} / \mathrm{L}$.

Although a direct comparison cannot be made for any of the wells because continuous water-quality data are not available, a visual comparison of the data on figure 16 shows many similarities in both datasets (early and late). In cases where sites from each dataset are in close proximity, the colors generally are similar, indicating a similar range in chloride concentration. Each dataset shows a sharper concentration gradient to the west, a slight spreading to the east of chloride concentrations from 100 to $500 \mathrm{mg} / \mathrm{L}$, and a bending to the southwest of the zone of elevated chloride concentrations south of Highway 8. In summary, the available data do not show major changes in the concentration or distribution of chloride concentrations in Area II.

As previously noted, because of the lack of data sufficient for statistical trend analysis, determining changes in chloride concentration and assessing spreading or dilation of the zone of elevated chloride concentrations in Area II can be approached only on a general regional perspective. A longterm sampling program targeting select sites based on the distribution of concentrations in figure 9 would enable defining trends and predicting movement of saline water in Area II. This type of information is especially important for farmers near the western boundary of the zone of elevated chloride concentrations, where pumping-induced changes in chloride concentrations can occur within short timeframes because of the sharp concentration gradients. Agricultural activities in the area have changed in recent years. Several fish farms have ceased operations because of market and economic conditions. In addition, shifts in pumping schedules and the areal distribution of wells that occur with changing agricultural practices 

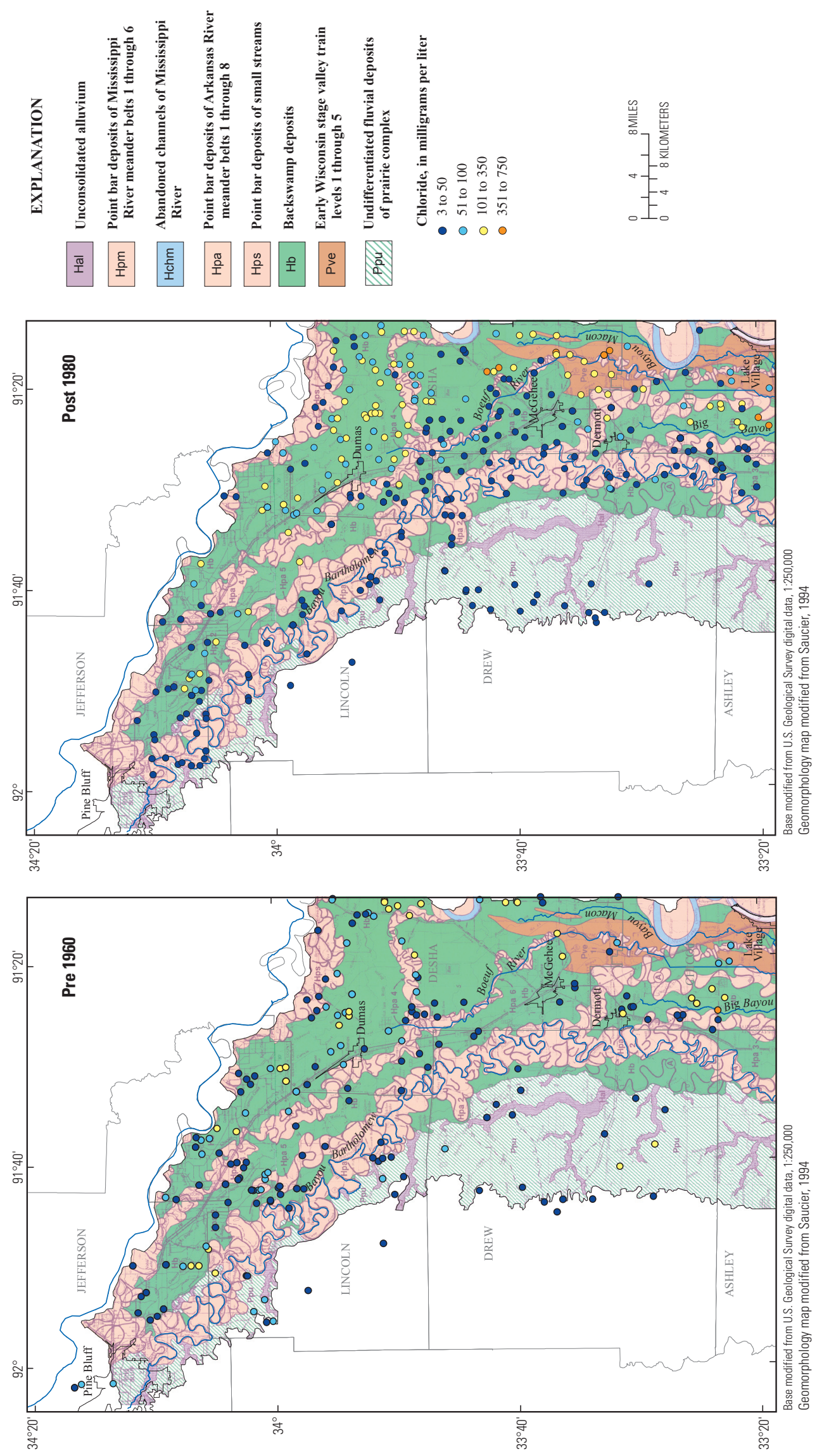

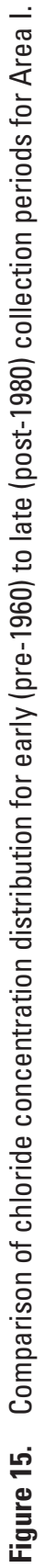




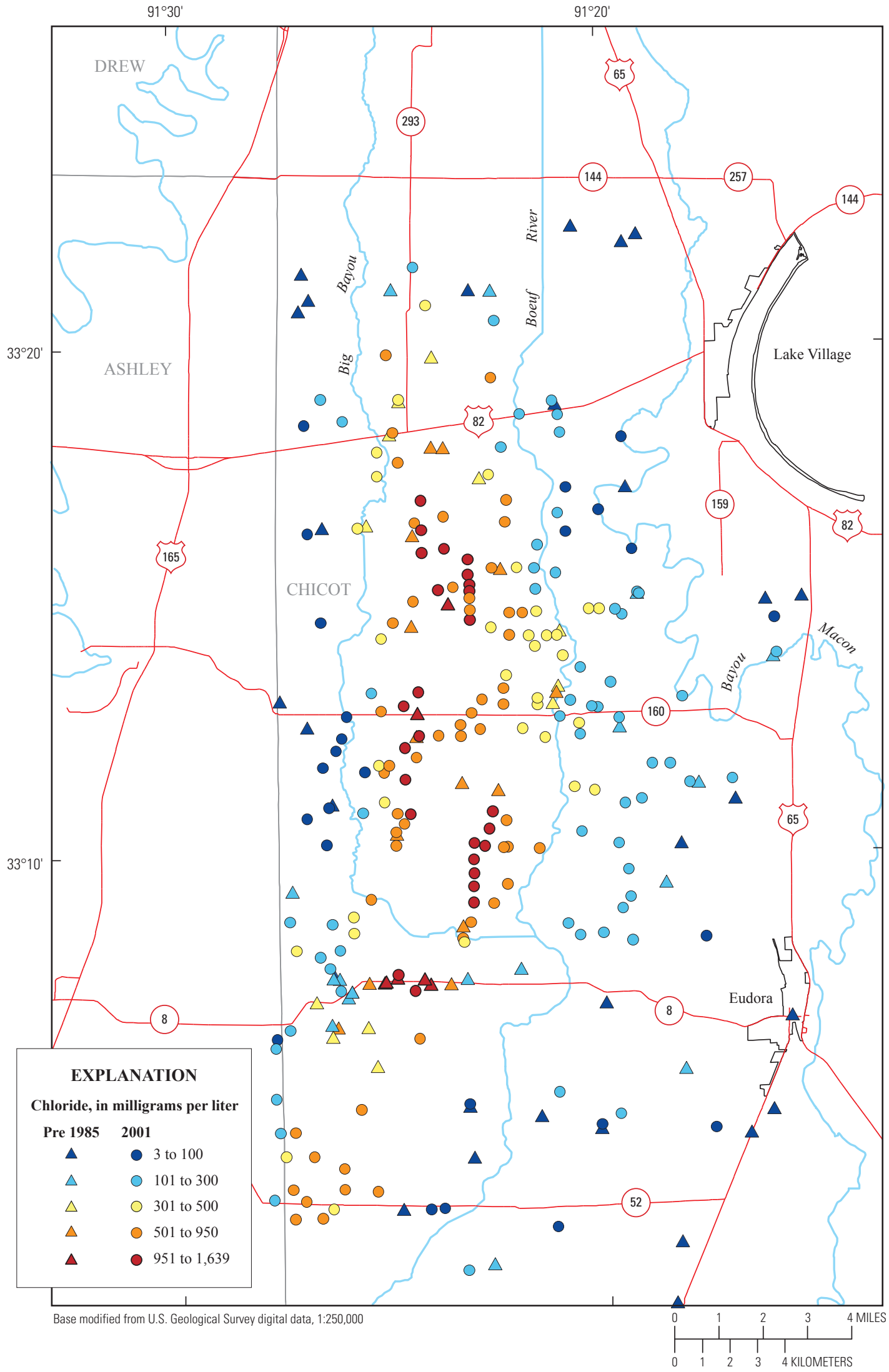

Figure 16. Comparison of early (pre-1985) U.S. Geological Survey data to late (2001) Arkansas Department of Environmental Quality data for Area II. 
could result in pumping-induced changes in local flow directions sufficient to change concentrations where the concentration gradients are steep.

\section{Summary}

The Mississippi River Valley alluvial aquifer is the primary source of irrigation water in eastern Arkansas and has the largest withdrawals of any aquifer in the State. Irrigation use accounted for $6,942 \mathrm{Mgal} / \mathrm{d}$ or 92 percent of the total ground water used during 2005. One of the more important water-quality concerns related to agricultural production is saline water. Problems encountered in the use of saline waters for irrigation in Arkansas include the burning of crop foliage and chronic effects such as a reduction in the plants ability to take up water as a result of an increase in the osmotic pressure of soils. As such, a ground-water chloride concentration of 100 $\mathrm{mg} / \mathrm{L}$ is recommended as the upper limit for use on rice.

Water-quality data were gathered from various sources resulting in approximately 2,500 sites across a six-county area in southeastern Arkansas and used to produce a map of the occurrence and distribution of chloride concentrations in the alluvial aquifer, to evaluate potential chloride sources, and to interpret temporal trends in chloride concentrations. The distribution and range of chloride concentrations in the study area reveal distinct areas of elevated (greater than $100 \mathrm{mg} / \mathrm{L}$ ) chloride concentrations. Area I includes an elongated, generally northwest-southeast trending band of moderately elevated chloride concentrations beginning in southeastern Jefferson County, extending through Lincoln County and a small part of northeastern Drew County, and into Desha County. This band of elevated chloride concentrations is approximately 40 miles in length and varies from approximately 2 miles in width in Jefferson County to approximately 9 miles or greater in Desha County, with a maximum chloride concentration of $360 \mathrm{mg} / \mathrm{L}$. Area II is a narrow, north-south trending band of elevated chloride concentrations in southwestern Chicot County, with a maximum chloride concentration of $1,639 \mathrm{mg} / \mathrm{L}$. A zone of chloride concentrations exceeding $200 \mathrm{mg} / \mathrm{L}$ is approximately 25 miles in length and 5-6 miles in width.

In Area I, documented potential sources of chloride include infiltration from the Arkansas River, upward flow of saline water from the underlying upper Claiborne aquifer, and increases in salinity from slow percolation coupled with evapotranspiration in low recharge areas. Low chloride concentrations in wells next to the Arkansas River and in samples from the upper Claiborne aquifer, which underlies the alluvial aquifer, indicate that leakage from the river and upward flow of saline water from underlying aquifers are not likely sources for the high salinity water in the alluvial aquifer in Area I. A good comparison was noted between chloride concentrations in Area I and the surface geomorphology. In the majority of cases, elevated chloride concentrations occurred in backswamp deposits, with low concentrations (less than $50 \mathrm{mg} / \mathrm{L}$ ) in areas of active or abandoned channel deposits. A combination of advective flushing and relatively coarser material near to the channel deposits keeps chloride concentrations low in parts of the backswamp deposits closest to the channels. Where backswamp deposits are large in extent and the channel deposits are further removed from one another, recharge is minimal, little to no flushing occurs, and ground-water chloride concentrations are the greatest. The fine-grained, clayrich deposits associated with backswamp areas likely restrict recharge, induce increased ratios between evapotranspiration and recharge, and experience minimal flushing of salts concentrated during evapotranspiration.

A chloride mass balance method was employed to evaluate the potential recharge rates necessary to increase chloride concentrations in Area I, and using a maximum chloride concentration in Area I of $360 \mathrm{mg} / \mathrm{L}$ resulted in a recharge rate of $0.07 \mathrm{in} / \mathrm{yr}$. This value is at the extreme low end of regional recharge rates listed for humid areas of the United States, and represents a theoretical point recharge rate for small areas representative of lower permeability surficial deposits that are more conducive to generation of greater salinity values because of high evapotranspiration/recharge ratios. Previous studies listed four recharge rates for recalibration of a ground-water flow model of the alluvial aquifer in southeastern Arkansas, with values ranging from $0.83 \mathrm{in} / \mathrm{yr}$ to $2.5 \mathrm{in} / \mathrm{yr}$. The lower value of $0.83 \mathrm{in} / \mathrm{yr}$ integrated recharge over a large area, which included backswamp and channel deposits and did not account for local, small-scale variation of soil type and recharge rates. The lowest chloride concentration of $3.2 \mathrm{mg} / \mathrm{L}$ for Area I resulted in an estimated high-end recharge rate of $7.81 \mathrm{in} / \mathrm{yr}$. As such, both the low and high chloride concentrations in Area I theoretically represent the variation of localized effects of soil type, climatic effects, and evapotranspiration, and bracket the range of estimated recharge rates provided for the flow model. The median chloride concentration of 36.5 $\mathrm{mg} / \mathrm{L}$ for Area I equates to an estimated recharge rate of 0.68 in/yr using the chloride mass balance method, which compares well with the lowest recharge rate of $0.83 \mathrm{in} / \mathrm{yr}$ used in the flow model for areas with clayey topstratum.

In Area II, documented potential sources of chloride included upward leakage of saline water from underlying Tertiary aquifers, encroachment of saline water through abandoned oil exploration wells, and movement of water along faults extending into deep, brine-producing formations. Chloride isoconcentration maps of the underlying upper Claiborne aquifer, in addition to samples from wells completed in the underlying middle and lower Claiborne aquifers, showed a similar chloride distribution to that of the alluvial aquifer with decreasing chloride concentrations to the east of the zone of elevated chloride concentrations. Mixing curves developed from bromide/chloride ratios in water samples from the alluvial aquifer, Tertiary aquifers, and samples of brine water from the Smackover Formation additionally discount upward flow of saline water from underlying Tertiary formations as a potential mechanism for salinity in the alluvial aquifer in Area II. A review of information on oil exploration wells in Chicot 
County revealed that most of these wells were drilled from 1960 to 1980, after the documentation of elevated chloride concentrations in samples collected from 1952 to 1953. One exploration well drilled in 1944 was located near the southern edge of the zone of elevated chloride concentrations in Area II, but chloride concentrations in samples from alluvial wells in the vicinity of this well were considerably lower than the maximum chloride concentrations in Area II. The occurrence of "salty" water was noted in the early 1900s for a horizon 800-1,000 feet deep in northern Moorehouse Parrish and in West Carroll Parrish in northern Louisiana, immediately south of Chicot County. The zone of elevated chloride in Area II in this report is contiguous with and extends into northern Louisiana and each area was associated with the same source, and a well completed 800-1,000 feet deep would be completed in the Claiborne aquifer. As such, the occurrence of saline water in Tertiary formations from samples collected prior to 1900 would tend to discount encroachment through abandoned oil and gas wells.

The elongated nature of the zone of elevated chloride concentrations in Area II has been noted in previous investigations as suggesting a line source or linear conduit connection with the source, rather than a point source of contamination. Maps constructed of a fractured limestone in the Jurassic Smackover Formation for the purpose of hydrocarbon exploration in Arkansas, Mississippi and Louisiana revealed the intersection of two wrench faults in the vicinity of Area II. At least one of the faults was noted as extending into the Smackover Formation and was listed as having been active as late as the Pleistocene or Holocene Periods. As such, upward movement of briny water in the Smackover Formation along these faults in southern Chicot County could introduce saline water into the alluvial aquifer.

County-level, temporal-trend analysis of mean chloride concentrations in parts of Area I indicate that chloride concentrations have changed little from concentrations documented previous to 1950. Similarities were noted for general water quality collected in1996 and that of previous investigations dating back to 1948. Ground-water samples collected from the alluvial aquifer in Jefferson County in 1996 had a mean chloride concentration of $35 \mathrm{mg} / \mathrm{L}$ compared to a mean concentration of $39 \mathrm{mg} / \mathrm{L}$ for samples collected in 1948-1949. In Desha County, the mean chloride concentration for samples collected in 1996 was $62 \mathrm{mg} / \mathrm{L}$ compared to a mean concentration of 56 $\mathrm{mg} / \mathrm{L}$ for samples collected in 1952. Maps of chloride concentrations for data collected prior to 1960 (1946-1959) were compared to maps of chloride concentrations for data collected after 1980 ( greater than 75 percent of samples collected after 1995) to inspect for spatial differences that might indicate temporal trends. There was a strong similarity between both maps for the occurrence of greater concentrations in the backswamp deposits and the lower concentrations in the active and abandoned channel deposits. As such, no temporal trends in chloride concentrations were identified for Area I.

Trend analysis was more difficult for Area II as insufficient data were available for earlier datasets. Data collected from 1950 to 1984 were used to represent an early period for comparison to a later 2001 dataset. The data generally showed close agreement of both data sets. In cases where sites from each dataset were in close proximity, the data indicated a similar range in chloride concentration. Each dataset showed a sharper chloride concentration gradient to the west, a slight spreading to the east of chloride concentrations from 100 to $500 \mathrm{mg} / \mathrm{L}$, and a bending to the southwest of the zone of elevated chloride concentrations in the southern part of the study area. As such, the overall shape and size of the zone of elevated chloride concentrations has remained relatively static based on the available data. 


\section{References Cited}

Ackerman, D.J., 1989, Hydrology of the Mississippi River Valley alluvial aquifer, South-Central United States - A preliminary assessment of the regional flow system: U.S. Geological Survey Water-Resources Investigation Report, $88-4028,74 \mathrm{p}$.

Ackerman, D.J., 1996, Hydrology of the Mississippi River Valley alluvial aquifer, South-Central United States: U.S. Geological Survey Professional Paper 1416-D, 56 p.

Appelo, C.A.J., and Postma, D., 1999, Geochemistry, groundwater and pollution: Brookfield, Vt, A.A. Bakema Publishers, $536 \mathrm{p}$.

Allison, G.B., and Hughes, M.W., 1978, The use of environmental chloride and tritium to estimate total recharge to an unconfined aquifer: Australian Journal of Soil Research, v. 16, no. 2, p. 181-195.

Bedinger, M.S., and Jeffery, H.G., 1964, Ground water in the Lower Arkansas River Valley, Arkansas: U.S. Geological Survey Water-Supply Paper 1669-V, 17 p.

Bedinger, M.S., and Reed, J.E., 1961, Geology and groundwater resources of Desha and Lincoln Counties, Arkansas: Arkansas Geology and Conservation Commission Water Resources Circular 6, 129 p.

Boswell, E.H., Cushing, E.M., and Hosman, E.L., 1968, Quaternary aquifers in the Mississippi Embayment, with discussion on Quality of the water, by H.G. Jeffery: U.S. Geological Survey Professional Paper 448-E, 15 p.

Broom, M.E., and Reed, J.E., 1973, Hydrology of the Bayou Bartholomew alluvial aquifer-stream system, Arkansas: U.S. Geological Survey Open-File Report 73-34, 91 p.

Cardon, G.E., and Mortvedt, J.J., 2001, Salt affected soils: Fort Collins, Colo, Colorado State University Cooperative Extension Service, $5 \mathrm{p}$.

Delin, G.N., and Risser, D.W., 2007, Ground-water recharge in humid areas of the United States - A summary of groundwater resources program studies, 2003-06: U.S. Geological Survey Fact Sheet FS-2007-3007, 4 p.

Fisk, H.N., 1944, Geological investigation of the alluvial valley of the lower Mississippi River: Vicksburg, Miss., U.S. Army Corps of Engineers, Waterways Experiment Station, $78 \mathrm{p}$.

Fishman, M.J., ed., 1993, Methods of analysis by the U.S. Geological Survey National Water Quality Laboratory-Determination of inorganic and organic constituents in water and fluvial sediments: U.S. Geological Survey Open-File Report 93-125, $217 \mathrm{p}$.
Fitzpatrick, D.J., 1985, Occurrence of saltwater in the alluvial aquifer in the Boeuf-Tensas Basin, Arkansas: U.S. Geological Survey Water-Resources Investigations Report 85-4029, 1 sheet.

Freiwald, D.A., 1984, Average annual precipitation and runoff in Arkansas, 1951-80: U.S. Geological Survey Water-Resources Investigation Report 84-4363, 1 sheet.

Gilmour, J.T., 2000, Water quality in rice production: B.R. Wells Rice Research Studies 2000, Arkansas Agricultural Experiment Station, Research Series 485, p. 171-177.

Gonthier, G.J., and Mahon, G.L., 1994, Thickness of the Mississippi River Valley confining unit, eastern Arkansas: U.S. Geological Survey Water-Resources Investigations Report 92-4121, 4 sheets.

Haley, B.R., 1976 (revised 1993), Geologic map of Arkansas: U.S. Geological Survey, 1 sheet.

Hart, R.M., Clark, B.R., and Bolyard, S.E., 2008, Digital surfaces and thicknesses of selected hydrogeologic units within the Mississippi Embayment Regional Aquifer Study (MERAS): U.S. Geological Survey Scientific Investigations Report 2008-5098, accessed December 3, 2008, at http://pubs.er.usgs.gov/usgspubs/sir/sir20085098

Hewitt, F.A., Baker, R.C., and Billingsley, G.A., 1949 Groundwater resources of Ashley County, Arkansas: Arkansas University, Institute of Science and Technology, Research Series 14, $35 \mathrm{p}$.

Holland, T.E., 2007, Water use in Arkansas, 2005: U.S. Geological Survey Scientific Investigations Report 2007-5241, $32 \mathrm{p}$.

Huff, G.F., and Bonck J.P., 1993, Saltwater in shallow aquifers in east-central and northeastern Louisiana and southeastern Arkansas: U.S. Geological Survey Open-File Report 93-494, 29 p.

Klein, Howard, Baker, R.C., and Billingsley, G.A., 1950, Ground-water resources of Jefferson County, Arkansas: Arkansas University, Institute of Science and Technology Research Series 19, 44 p.

Kline, S.W., Kresse, T.M., Fazio, J.A., Prior, W.L., Hanson, W.D., Miller, R.A., Treece, T.M., 2006, The Arkansas River's alluvial aquifer in central Arkansas: Physical hydrogeology of the aquifer at Dardanelle [abs.]: Fayetteville, Ark., Proceedings of the Arkansas Water Resources Center Annual Conference, accessed October 7, 2008, at http://www.uark.edu/depts/awrc/ Publications/2006AWRCConference/TrifoldLF.pdf 
Kresse, T.M., and Fazio, J.A., 2002, Pesticides, water quality, and geochemical evolution of ground water in the alluvial aquifer, Bayou Bartholomew Basin, Arkansas: Arkansas Department of Environmental Quality, Water Quality Report WQ02-05-1, 111 p.

Kresse, T.M., Fazio, J.A., Hays, P.D., and Stanton, G.P., 2000, Sources of saltwater intrusion in the alluvial aquifer in parts of Chicot County, Arkansas, in Environmental Hydrology, Proceedings of the Arkansas Water Resources Center Annual Conference, Fayetteville, Ark., Ken Steele, ed.: Arkansas Water Resources Center Publication no. MSC284, p. 1-6.

Kresse, T.M., Fazio, J.A., Miller, R.A., and Kline, S.W., 2006, The Arkansas River's alluvial aquifer in central Arkansas: Geochemistry of the aquifer at Dardanelle [abs.]: Fayetteville, Ark., Proceedings of the Arkansas Water Resources Center Annual Conference, accessed October 7, 2008, at http://www.uark.edu/depts/awrc/ Publications/2006AWRCConference/TrifoldLF.pdf

Kresse, T.M., and Huetter, T.A., 1999, Ground-water resources and water quality in the vicinity of Pine Bluff municipal area, Jefferson County, Arkansas: Arkansas Department of Environmental Quality, Water Quality Report WQ99-10-1, $79 \mathrm{p}$.

Kresse, T.M., and Van Schaik, E.J., 1996, Preliminary results of pesticide investigation, Augusta, Arkansas: Arkansas Department of Pollution Control and Ecology, Special Investigation Report SI96-11-1, 17 p.

Kresse, T.M., Van Schaik, E.J., Wise, J., and Huetter, T., 1997. Occurrence of pesticides in alluvial aquifer of eastern Arkansas: Arkansas Department of Pollution Control and Ecology, Water Quality Report WQ97-10-1, 39 p.

Krinitzsky, E.L., and Wire, J.C., 1964, Ground water in alluvium of Lower Mississippi Valley (upper and central areas): U.S. Army Corps of Engineers, Waterways Experiment Station Technical Report 3-658, v. 1 and 2, 100 p.

Macfarlane, P.A., Clark, J.F., Davisson, M.L., Hudson, G.B., and Whittemore, D.O., 2000, Late-Quaternary recharge determined from chloride in shallow groundwater in the Central Great Plains: Quaternary Research, v. 53, p. 167-174.

Mahon, G.L., and Ludwig, A.H., 1990, Simulation of groundwater flow in the Mississippi River Valley alluvial aquifer in eastern Arkansas: U.S. Geological Survey Water-Resources Investigations Report 89-4145, 83 p.

McFarland, M.L., Lemon, R.G., and Stichler, C.R., 1998, Irrigation water quality - critical salt levels for peanuts, cotton, corn \& grain sorghum: Texas Agricultural Extension Service, Texas A\&M University, 4 p.
National Atmospheric Deposition Program (NRSP-3), 2008, NADP Program Office, Illinois State Water Survey, Champaign, Ill.

Oberg, G., 2003, The biogeochemistry of chlorine in soil, in Hutzinger, O., The Handbook of Environmental Chemistry, v. 3, Anthropogenic Compounds, Part P, Springer Publishers, p. 43-62.

Onellion, F.E., 1956, Geology and ground-water resources of Drew County, Arkansas: Arkansas Geology and Conservation Commission, Water Resources Circular 4, 32 p.

Onellion, F.E., and Criner, J.H., Jr., 1955, Ground-water resources of Chicot County, Arkansas: Arkansas Geology and Conservation Commission Water Resources Circular 3, $27 \mathrm{p}$.

Orr, L.A., Bauer, H.H., Wayenberg, J.A., 2002, Estimates of ground-water recharge from precipitation to glacial-deposit and bedrock aquifers on Lopez, San Juan, Orcas, and Shaw Islands, San Juan County, Washington: U.S. Geological Survey Water-Resources Investigations Report 02-4114, 113 p.

Payne, J.N., 1968, Hydrologic significance of the lithofacies of the Sparta Sand in Arkansas, Louisiana, Mississippi, and Texas: U.S. Geological Survey Professional Paper, 569-A, $17 \mathrm{p}$.

Petersen, J.C., 1988, Statistical summary of selected waterquality data (water years 1975 through 1985) for Arkansas rivers and streams: U.S. Geological Survey Water-Resources Investigations Report 88-4112, 189 p.

Prych, E.A., 1995, Using chloride and chorine-36 as soil-water tracers to estimate deep percolation at selected locations on the U.S. Department of Energy Hanford Site, Washington: U.S. Geological Survey Open-File Report 94-514, 125 p.

Pulley, H.J., and Beyrouty, C.A., 1996, Effect of salt type on soybean growth: Arkansas Soil Fertility Studies, Arkansas Agricultural Experiment Station Research Series 45, p. 84-87.

Reed, T.B., 2004, Status of water levels and selected waterquality conditions in the Mississippi River Valley alluvial aquifer in eastern Arkansas: U.S. Geological Survey Scientific Investigations Report 2004-5129, 53 p.

Rupe, J.C., Widick, J.D., Sabbe, W.E., Robbins, R.T., and Becton, C.B., 2000, Effect of chloride and soybean cultivar on yield and the development of sudden death syndrome, soybean cyst nematode, and southern blight: Plant disease: The American Phytopathological Society, v. 84, no. 6, p. 669-674.

Saucier, R.T., 1967, Geological investigation of the BoeufTensas Basin Lower Mississippi Valley: U.S. Army Corps of Engineers, Waterways Experiment Station Technical Report No. 3-757. 
Saucier, R.T., 1994, Geomorphology and Quaternary geologic history of the Lower Mississippi Valley, Volume I: U.S. Army Corps of Engineers, Waterways Experiment Station, Vicksburg, Mississippi, 400 p.

Scanlon, B.R., Reedy, R.C., and Keese, E.K., 2003, Estimation of groundwater recharge in Texas related to aquifer Vulnerability to contamination: Austin, Texas, The University of Texas Bureau of Economic Geology, 127 p.

Scanlon, B.R., 1991, Evaluation of moisture flux from chloride data in desert soils: Journal of Hydrology, v. 128, p. 137-156.

Schrader, T.P., 2001, Status of water levels and selected waterquality conditions in the Mississippi River Valley alluvial aquifer in eastern Arkansas, 2000: U.S. Geological Survey, Water-Resources Investigations Report 01-4124, 52 p.

Schrader, T.P., and Joseph, R.L., 2000, Potentiometric surfaces of aquifers in the Cockfield Formation in southeastern Arkansas and the Wilcox Group in southern and northeastern Arkansas, 2000: U.S. Geological Survey WaterResources Investigations Report 00-4206, 22 p.

Sharma, M.L., and Hughes, M.W., 1985, Groundwater recharge estimation using chloride, deuterium and oxygen-18 profiles in the deep coastal sands of western Australia: Journal of Hydrology, v. 81, p. 93-109.

Shurbaji, A.R., and Campbell, A.R., 1997, Study of evaporation and recharge in desert soil using environmental tracers, New Mexico, USA: Environmental Geology, v. 29, no. 3-4, Springer Berlin, publisher, p. 147-151.

Stanton, G.P., and Clark, B.R., 2003, Recalibration of a ground-water flow model of the Mississippi River Valley alluvial aquifer in southeastern Arkansas, 1918-1998, with simulations of hydraulic heads caused by projected groundwater withdrawals through 2049: U.S. Geological Survey Water-Resources Investigations Report 03-4232, 48 p.

Steele, K.F., Kresse, T.M., and Davis, R.K., 2003. Small-scale spatial variation of water quality within the Mississippi River Valley alluvial aquifer, Arkansas, USA, in Conference Proceedings of the 4th Joint IH-CNC/CGS Groundwater Specialty Conference, Winnipeg, Manitoba, Canada, 8 p.

Tacker, P., Langston, J., Ferguson, J., and Vories, E., 1994, Water management: Rice Production Handbook, University of Arkansas Cooperative Extension Service MP 192, p. 55-63.

U.S. Department of Agriculture, Soil Conservation Service, 1972, Soil survey of Arkansas: atlas, Washington, D.C., U.S. Government Printing Office.
Veatch, A.C., 1906, Geology and underground water resources of northern Louisiana with notes on adjoining districts: Geological Survey of Louisiana Report of 1905, Louisiana State Experiment Station, Louisiana Geology Survey Bulletin 4, p. 261-467.

Wang, D., and Shannon, M.C., 1999, Emergence and seedling growth of soybean cultivars and maturity groups under salinity: Plant and Soil, v. 214, no. 1-2, Springer Netherlands, p. 117-124.

Whitfield, M.S., Jr., 1975, Geohydrology and water quality of the Mississippi River alluvial aquifer, northeastern Louisiana: Louisiana Department of Public Works Water Resources Technical Report No. 10, 29 p.

Wilson, C.E., Jr., Frizzell, D.L., Scott, H.D., Norman, R.J., and Slaton, N.A., 2000, Summary characterization and spatial distribution of irrigation water quality parameters in Desha County, Arkansas, in Environmental Hydrology, Proceeding of the Arkansas Water Resource Center Annual Conference, Fayetteville, Ark., Ken Steele, ed.: Arkansas Water Resource Center Publication no. MSC-284, p. 7-12.

Wilson, C.E., Jr., Frizzell, D.L., Slaton, N.A., and Norman, R.J., 1997, Influence of seeding rates on rice salinity tolerance: B.R. Wells Rice Research Studies 1997, Arkansas Agricultural Experiment Station Research Series 460, p. 175-179.

Zimmerman, R.K., 1992, Fractured Smackover limestone in northeast Louisiana; implications for hydrocarbon exploitation: Gulf Coast Association of Geological Societies Transactions, v. 42, p. 401-412. 
Publishing support provided by:

Lafayette and Rolla Publishing Service Centers

For more information concerning the research described in the report::

U.S. Geological Survey

Arkansas Water Science Center

401 Hardin Road

Little Rock, AR 72211-3528

(501) 228-3600

http://ar.water.usgs.gov 


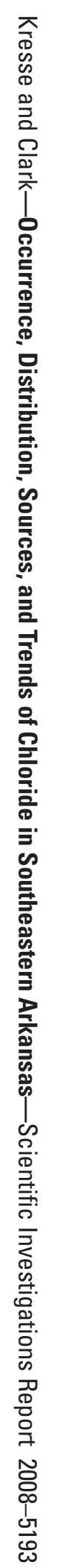

83 Printed on recycled paper 